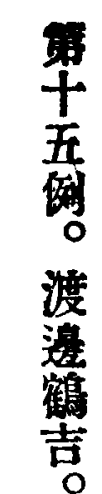

辛

年桂病

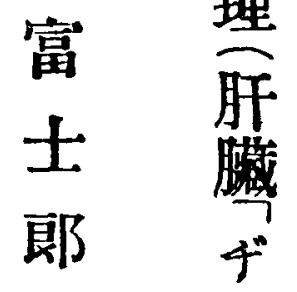

病

\section{管 奉}

7 亞

$r+$

+ 免

免

\section{的}

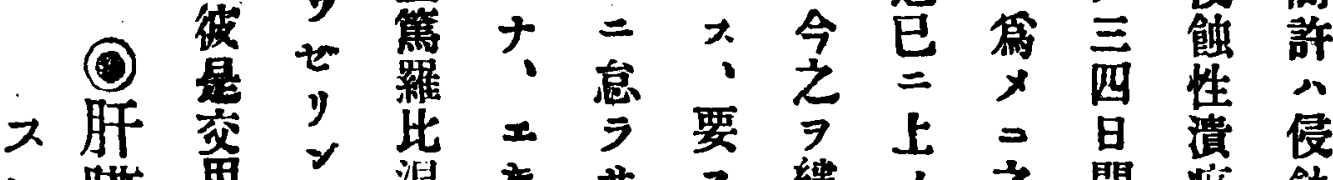

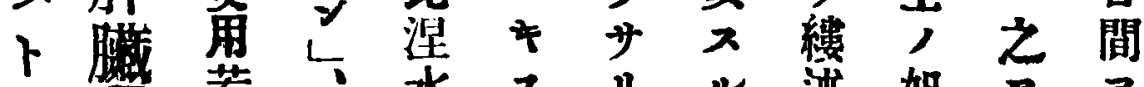

危藏荎永

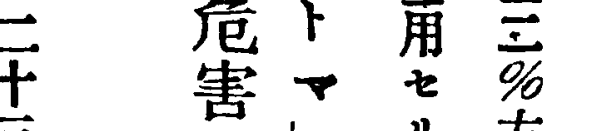
?. 克

㽞渠磁

永

及謨温

船希掌

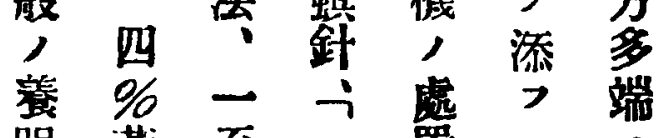

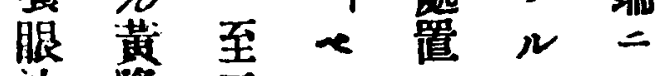

法降主う 諸 八战
权 $\sim 二$ 调 7 7 性 蕒除柊清 せ 多痛 三, 外 週 先 八. 間 駺 '許 刺 留 㐬 再 症称次 , 性, 海港四 退澺 週 機霹辈 能三 回失第
明

治

立 剖

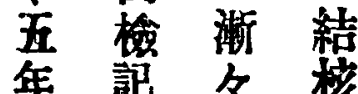

五事異性

月揭香

$+\quad \exists$ 胸

七䒼膜

旦

死亚結

后前核

六 + 格

㭙 七。㿢

間

$=$

$\Rightarrow$

部

儈

$x$
白膜

遂答

$=$ 。

死 肺

大 管
疼 $=$ 現七此 $=$ 閶

症琵旨本于篩

二年、昨待往

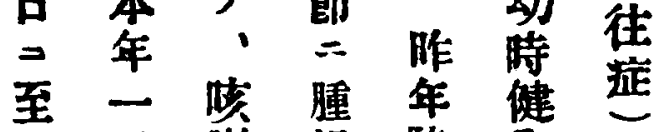

腹胸》月噘起壁全

壁部入九

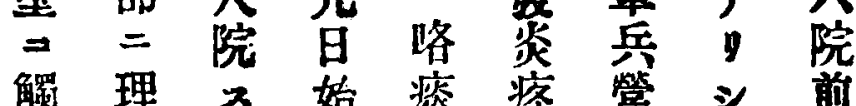

2 學 0

又烄

$\nu$ 旳

八診

啨 徵

$\rightarrow$ 著

抗 明

抵 右

强 肺

?、䏸

强界

今

糜第

7. 四

$\checkmark$ 助

三、氣在 7 等
于 發 $\mathrm{P} . P$

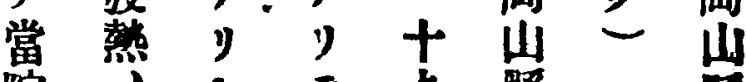

院: $\neq$ 无慗

二盜 0 在才御

來汁本胸, 野

》等 年 膜

$\Rightarrow$, 一 癷 間 今

治諸月７歇村

療 徵 $\exists$ 患熱 $\Rightarrow$

$\Rightarrow \Rightarrow y$ 七 $\Rightarrow$ 任

受來威: 䍜

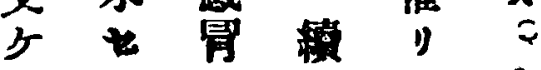

11, $>2$ 本
7 病

唡

爱 摘

二 夏

揭

牆

痛

7

院

患

者

井

上

八閶 


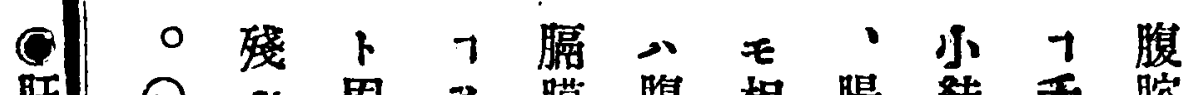

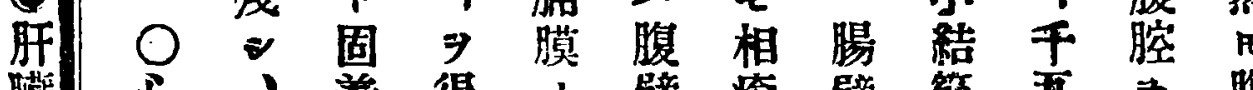

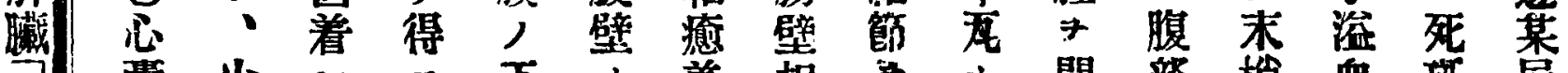

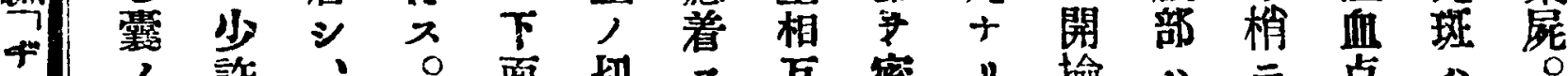

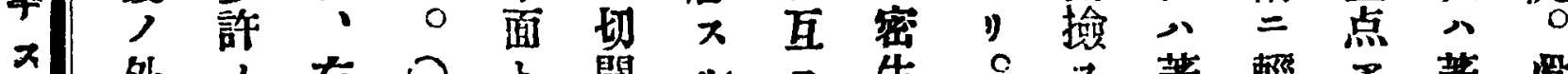

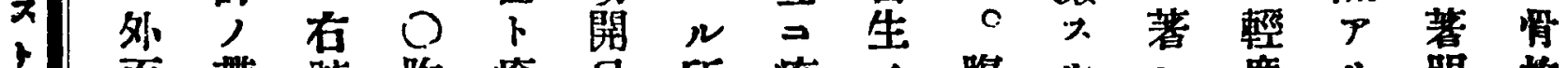

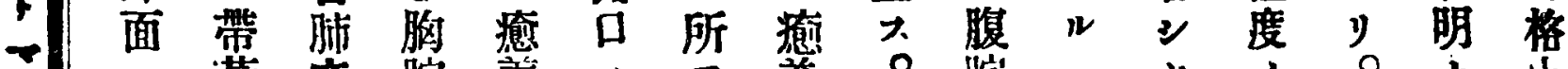

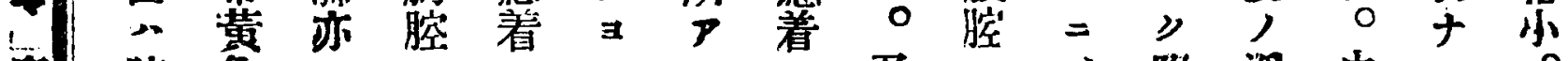

法 肺色 夕大

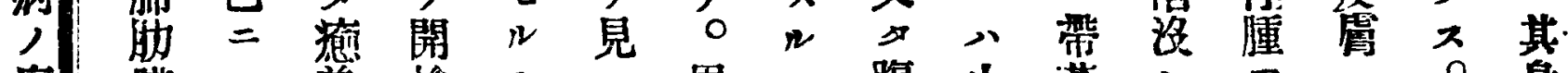

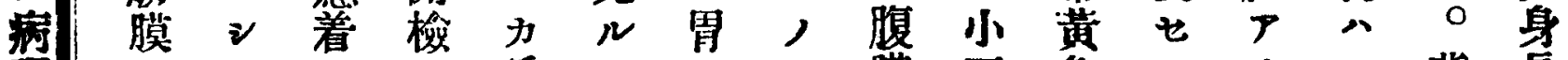

理 ト

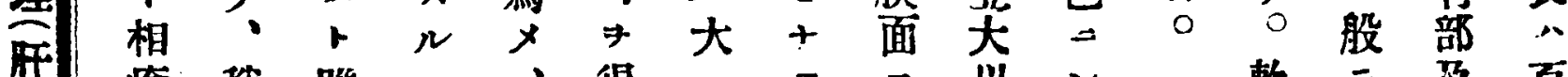

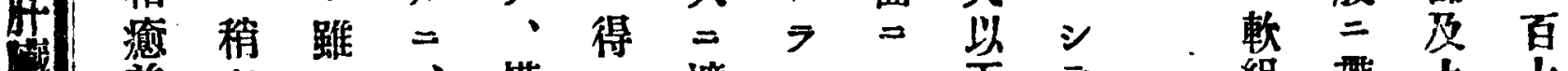

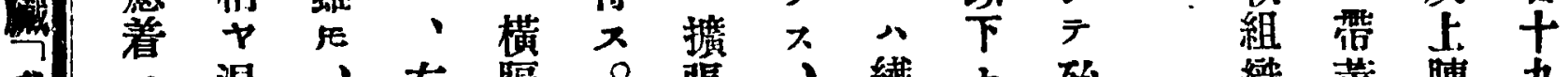

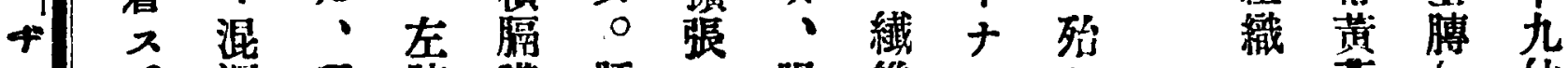

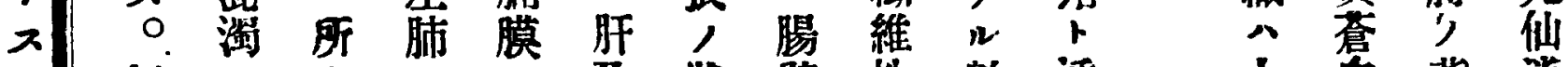

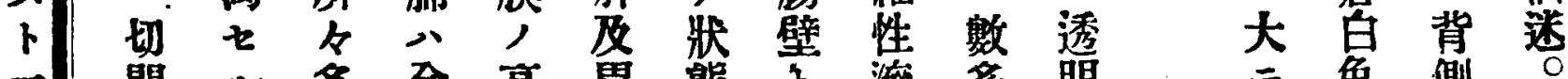

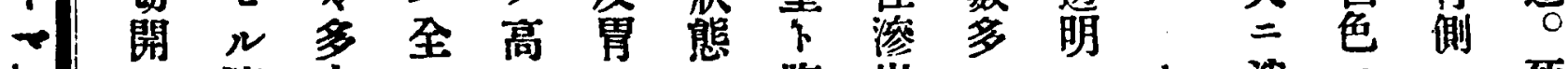

ᄂ 2 液少》少, 三腹出,

色

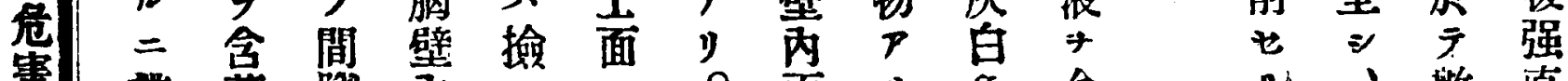

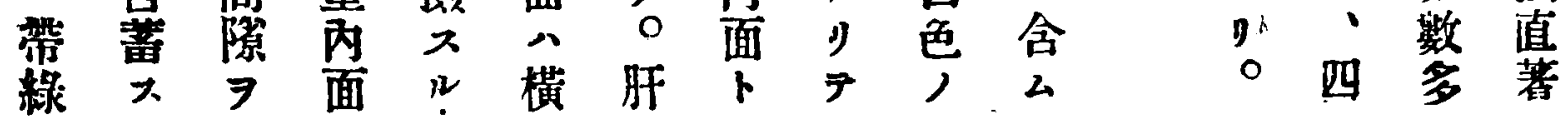

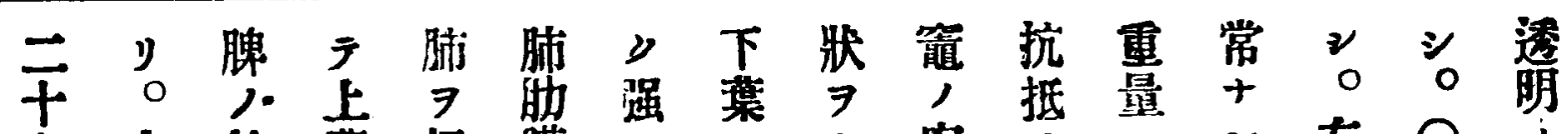

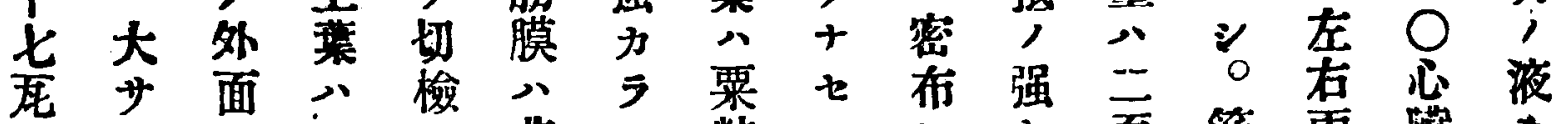

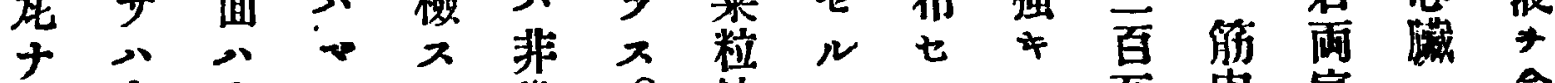
y士全，

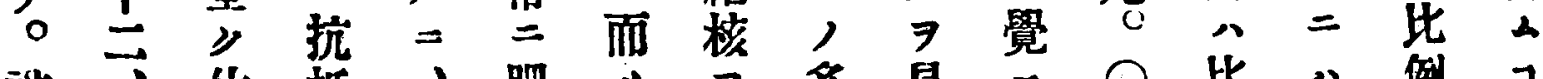

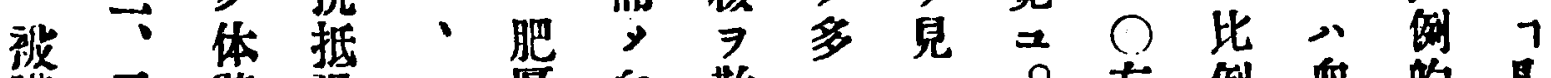
膜五壁强一厚血散 シ $几$ ○左例血的风

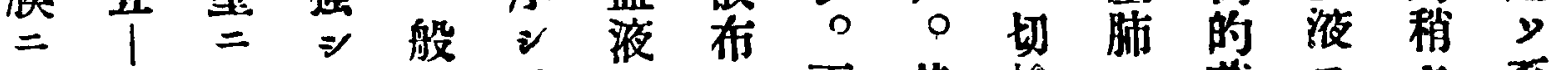

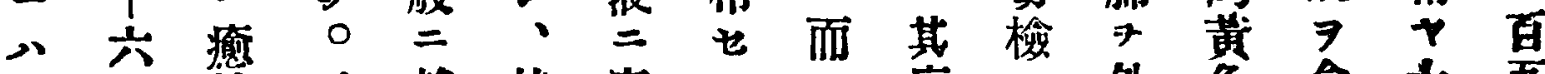

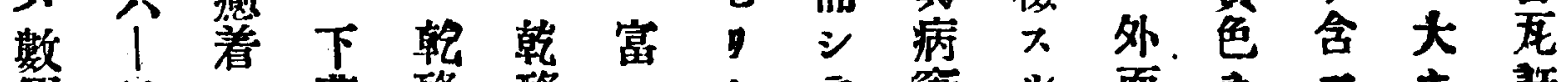

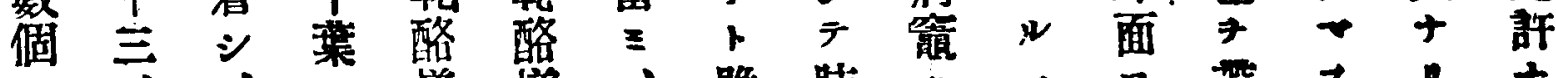

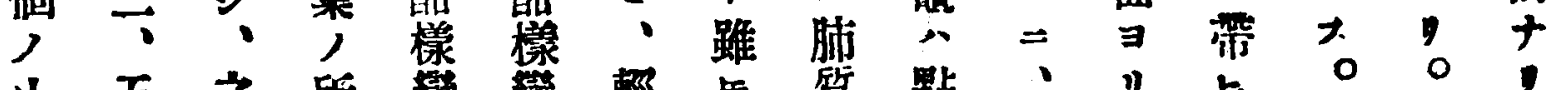

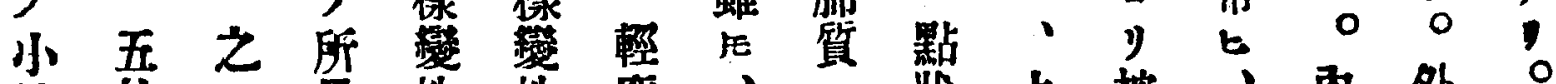

九結 仙 息性性度、心状上按、丙外。

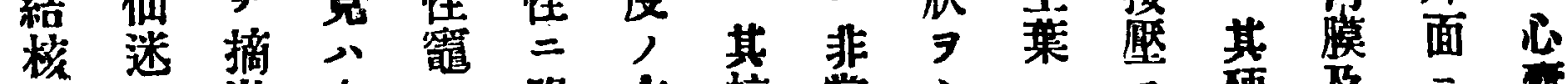
$P=$ 出左 $\neq$ 陷水抗常 +2 万硬及二

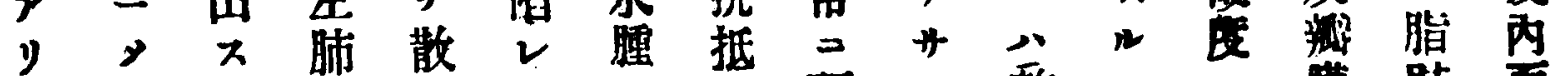

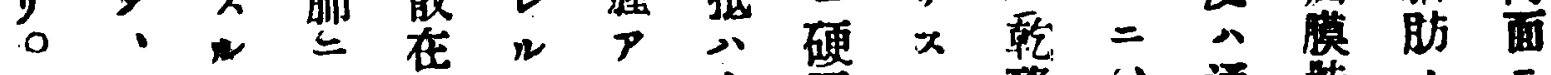

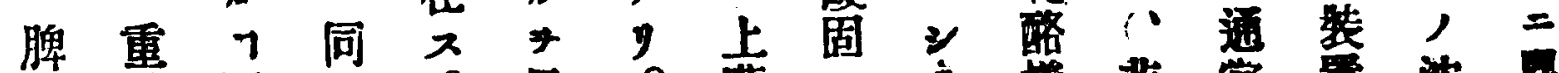

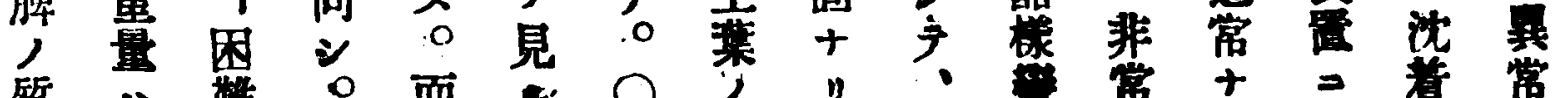

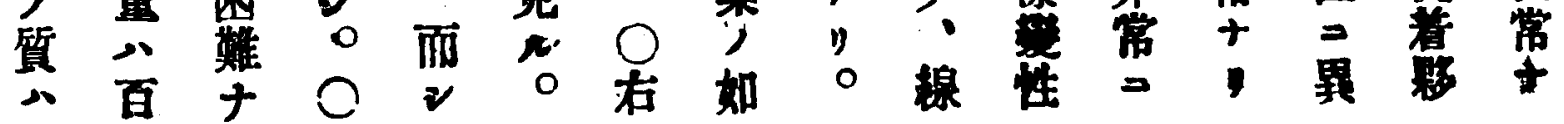




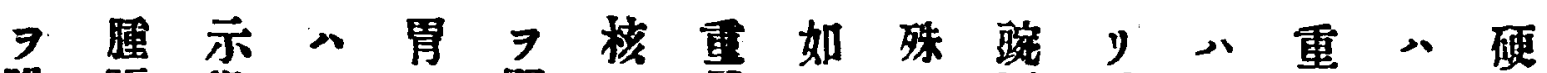
附脹指一 $\Rightarrow$ 開厂量方二豆。稍量十名

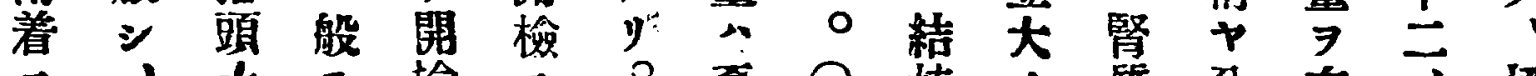

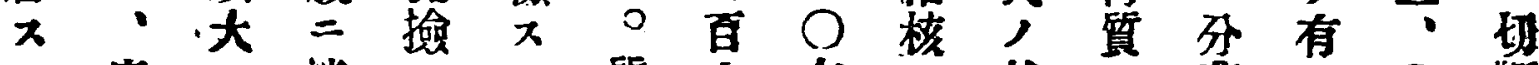

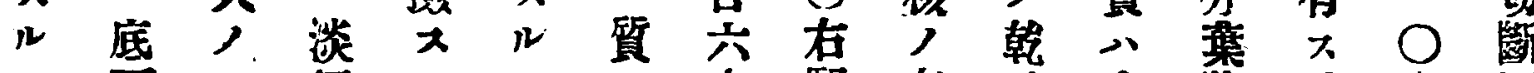

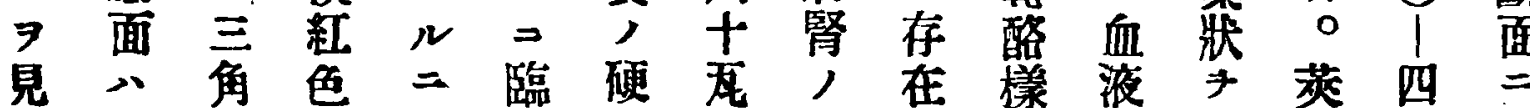

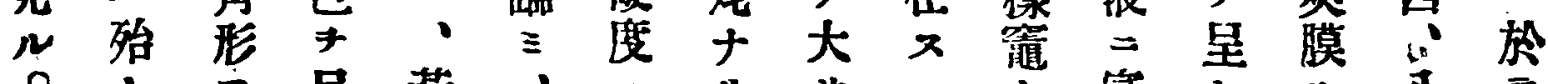

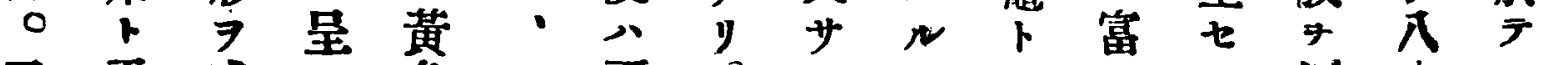

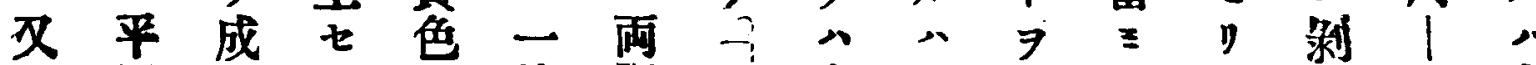

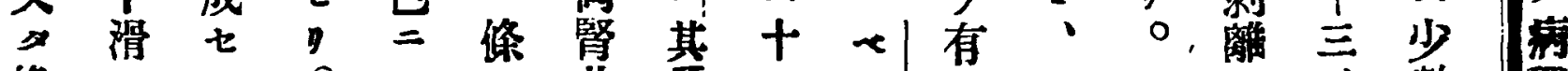
緣十ル○三其兵

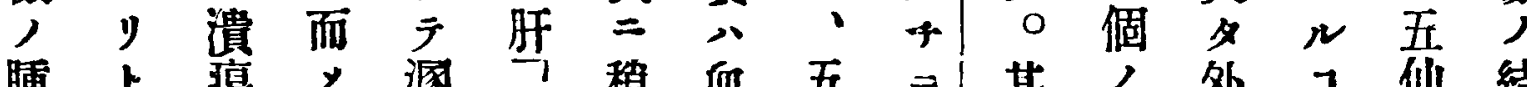

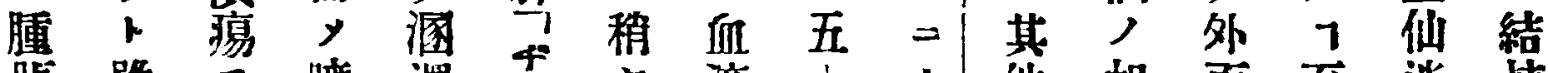

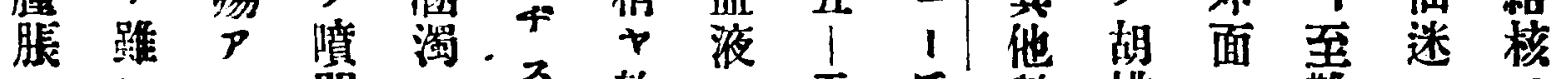
七 $E y$ 門 $九$ 㳄三五氏数桃三難,

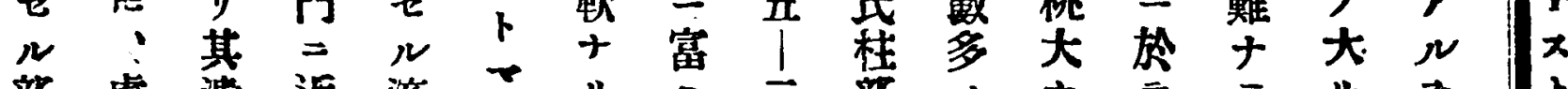

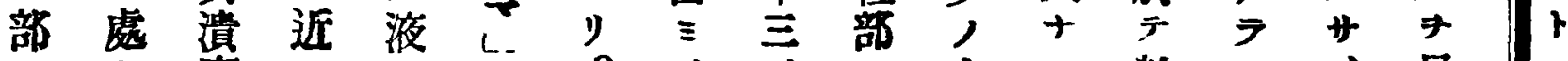

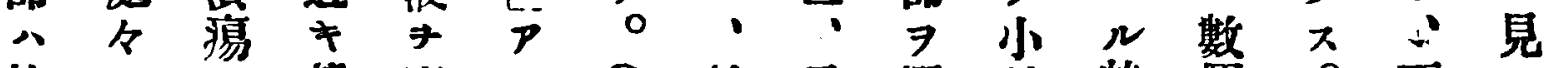

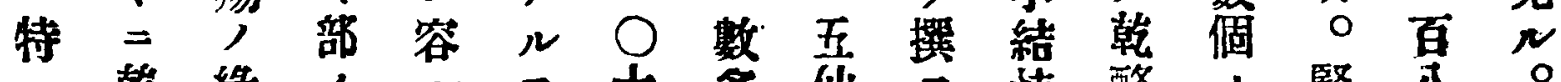

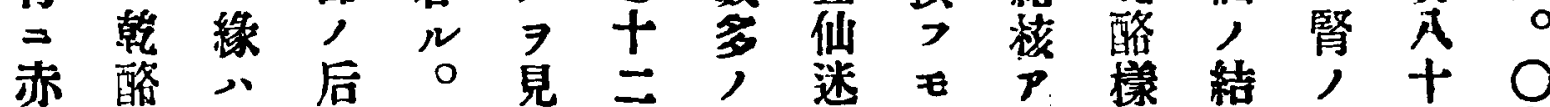

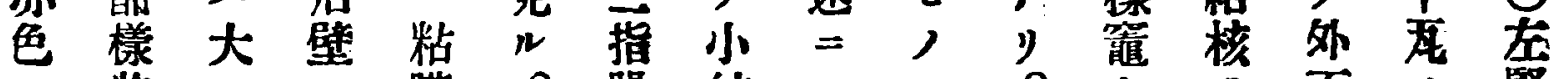

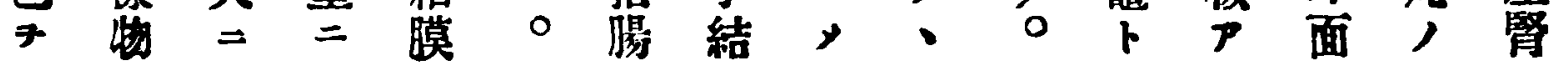

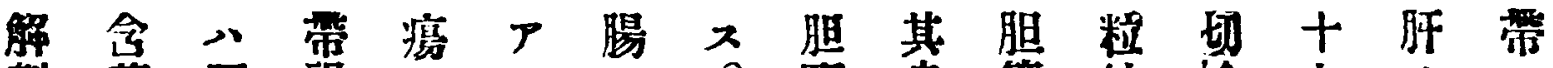
剖蓄可褐乃り人事蟲管結捡六人一

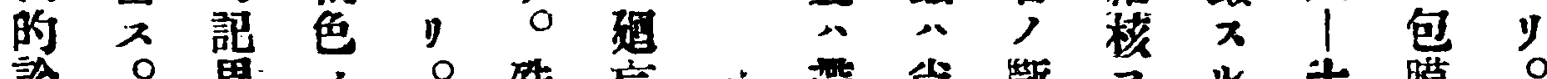

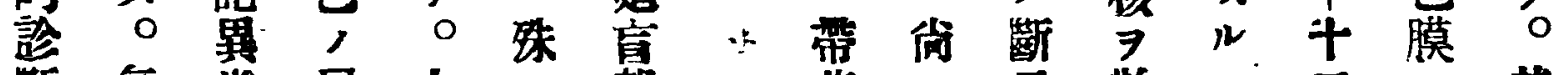
斷氣常尿大 $大$ 部 黄

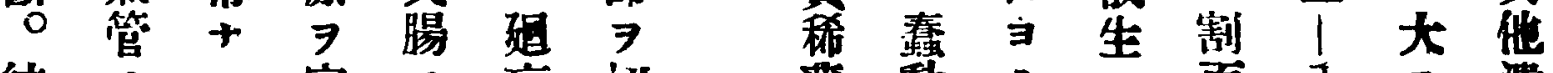

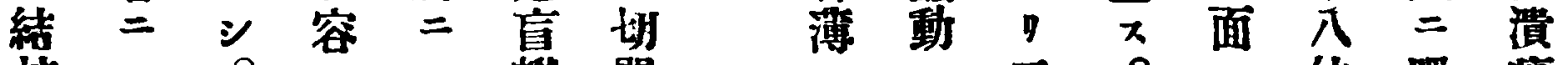

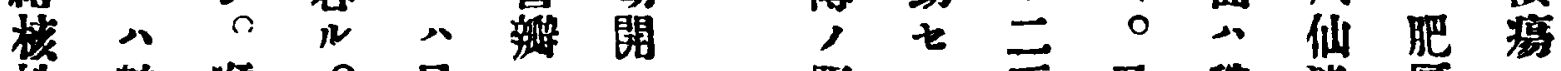

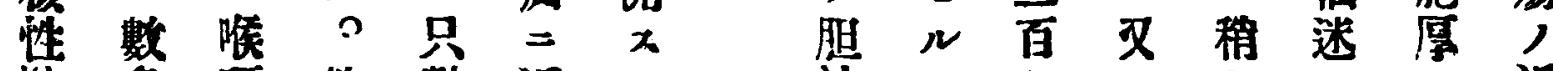

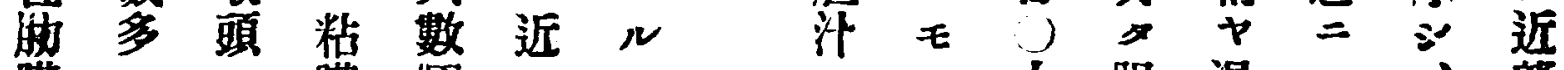

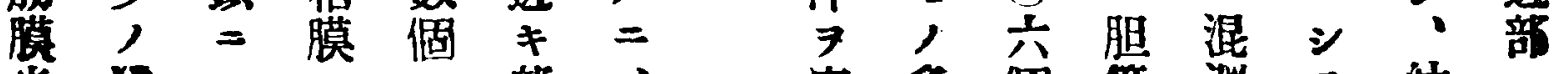

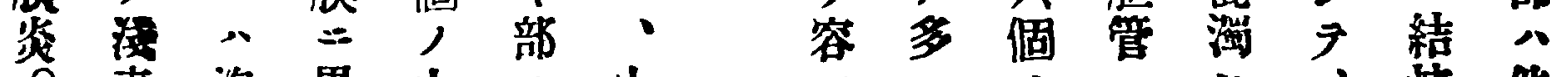

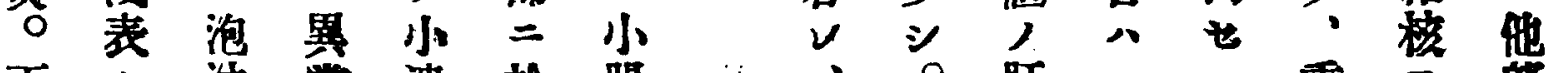

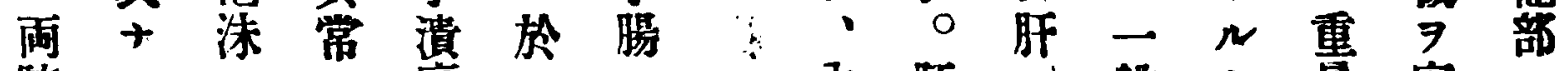

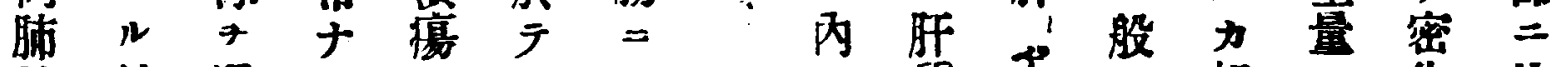

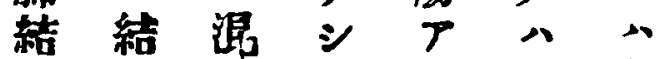

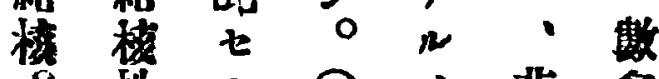
性, $\mathrm{O}$, 非多 䏦请多圆三常,

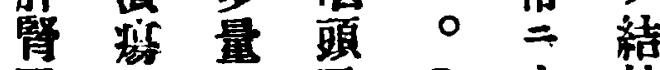
及大, 䐺、液食勝ナ性 ；。化通肤心清

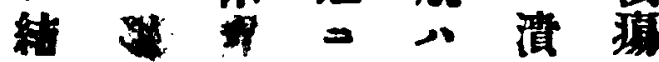

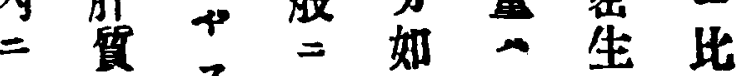

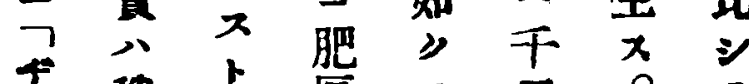

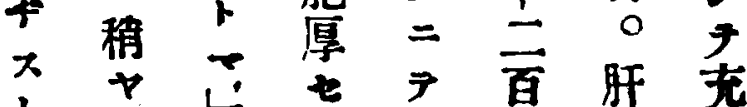

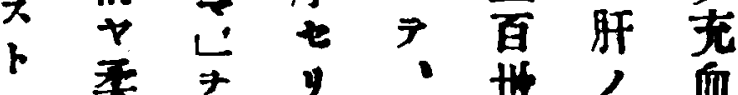

r委 $\neq y$, 相，血

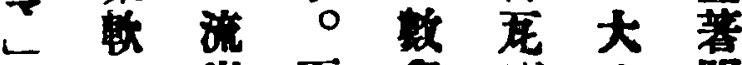

马十出面罗方萌

混 y x * 


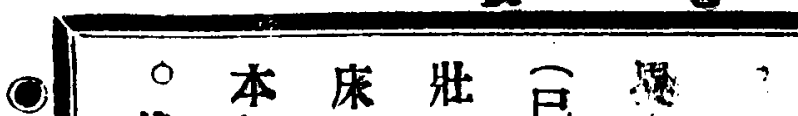

其年 $九+$ 徍

病全ルリ症

狀月 7 拝

又恰草五》

入恰 $\mathrm{H}+$ 入揭摘

上 王

病 冒 者二才

, $=>\approx$, 岡

满䍜 出 頃

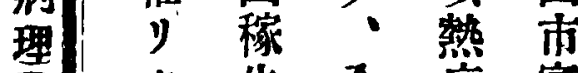

肝 夕先 全病富

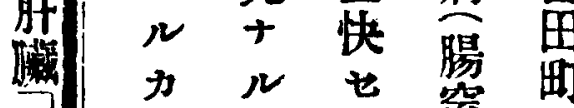

）如大 窒

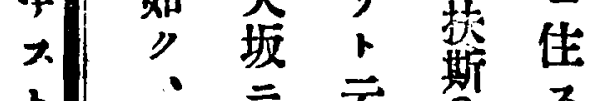

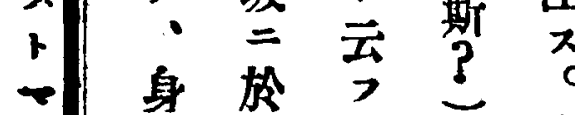

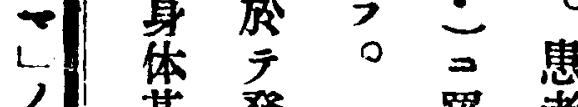

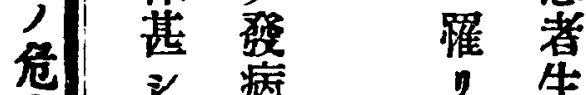

害 榙

》

疲y
、泰

就 强
請

天
第\#世其 八肝所

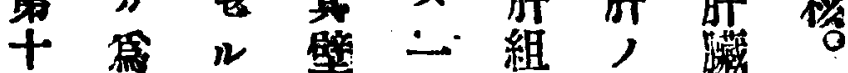

六 $x モ 三$ 般織

例荧, 於 $\Rightarrow$ 中 微

起罗与肥散 鏡

國 $シ$ 厚在的

本 夕

7 粘

寻 粘七 性

周金心見液り。見

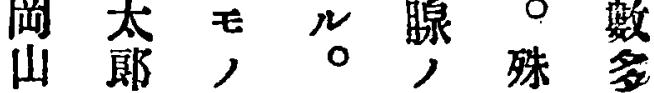

䟢。ナ然大

病二り比三稍

院十上他增 $ヤ$ 結

入八詺三息大核

院年山方主士性

患。可兵テル人

者力方去浸

役蛲占腺, 淍

井者化し脏二篦

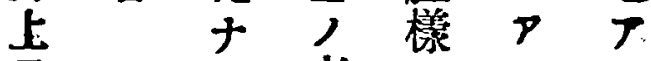

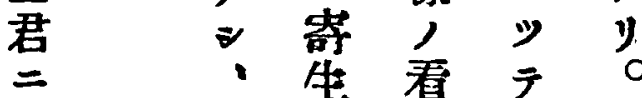

生看 テ

成、管
晹

7.

7. 結

結

性

溃

筩㾤

生。

腹

水 結

模

性

灣

瘍

腹

膜

結

核

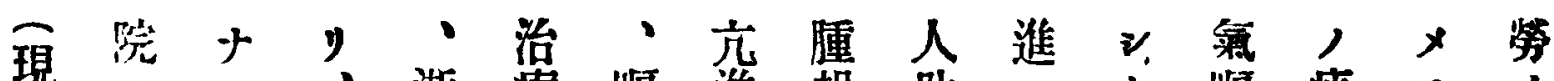
症 三 投 7 便 名

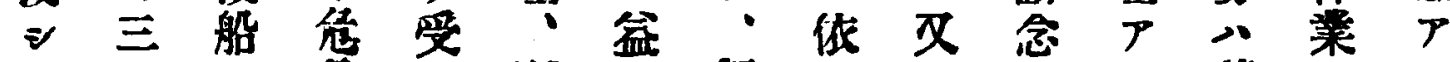
体、日

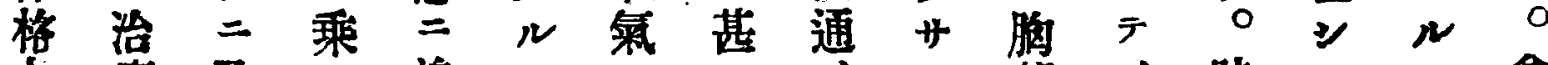

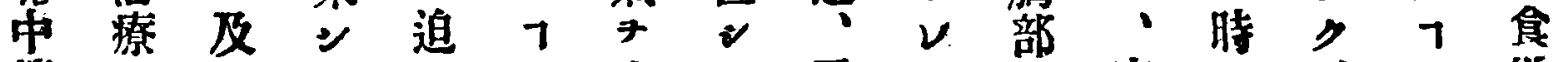

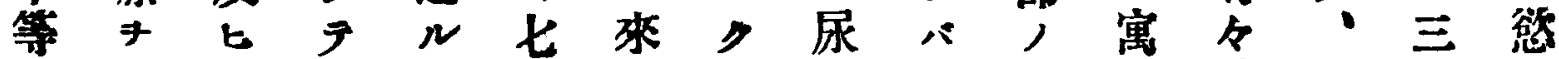
受 2 卿入 $>$ 、利起中所晆心旦三 策方里傾

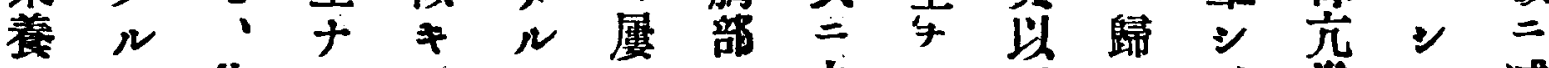
八7 佳 甚卜徴閏

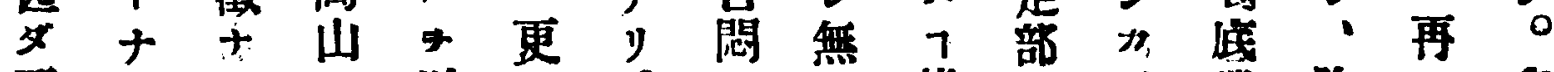

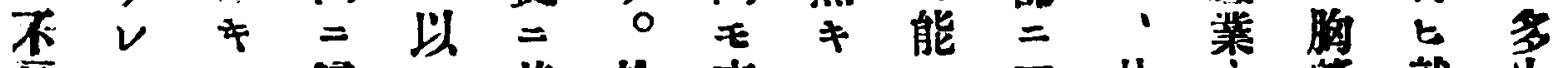

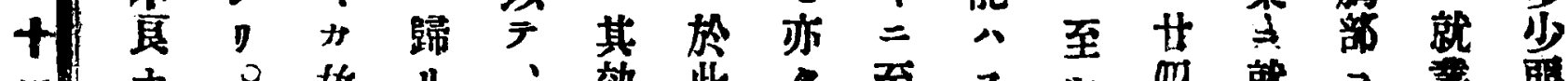

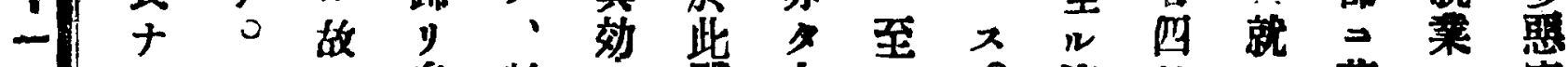

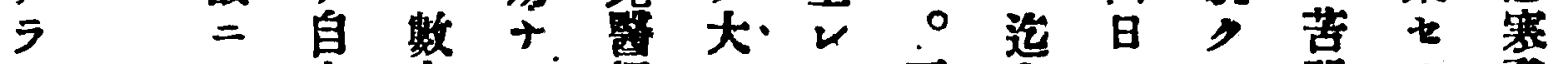

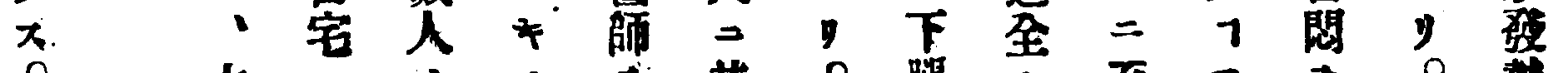

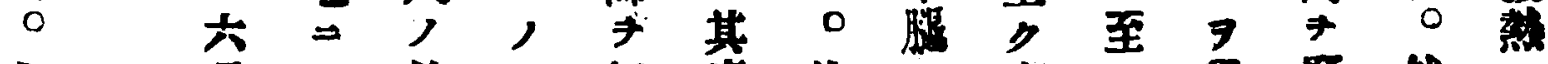

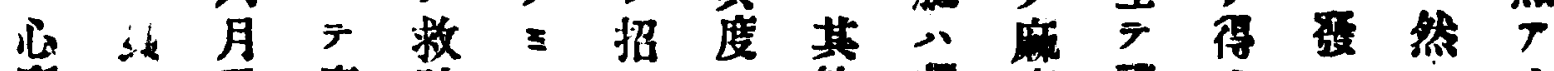

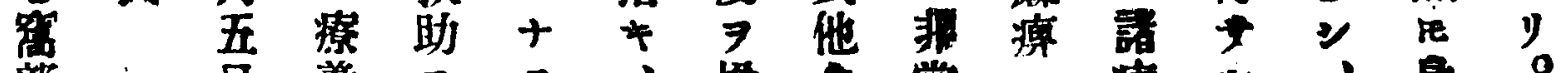

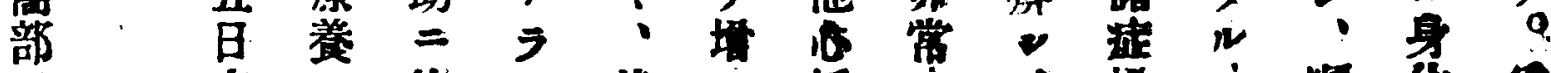

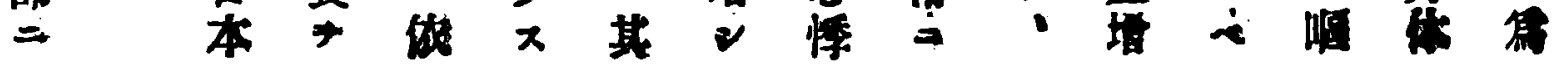




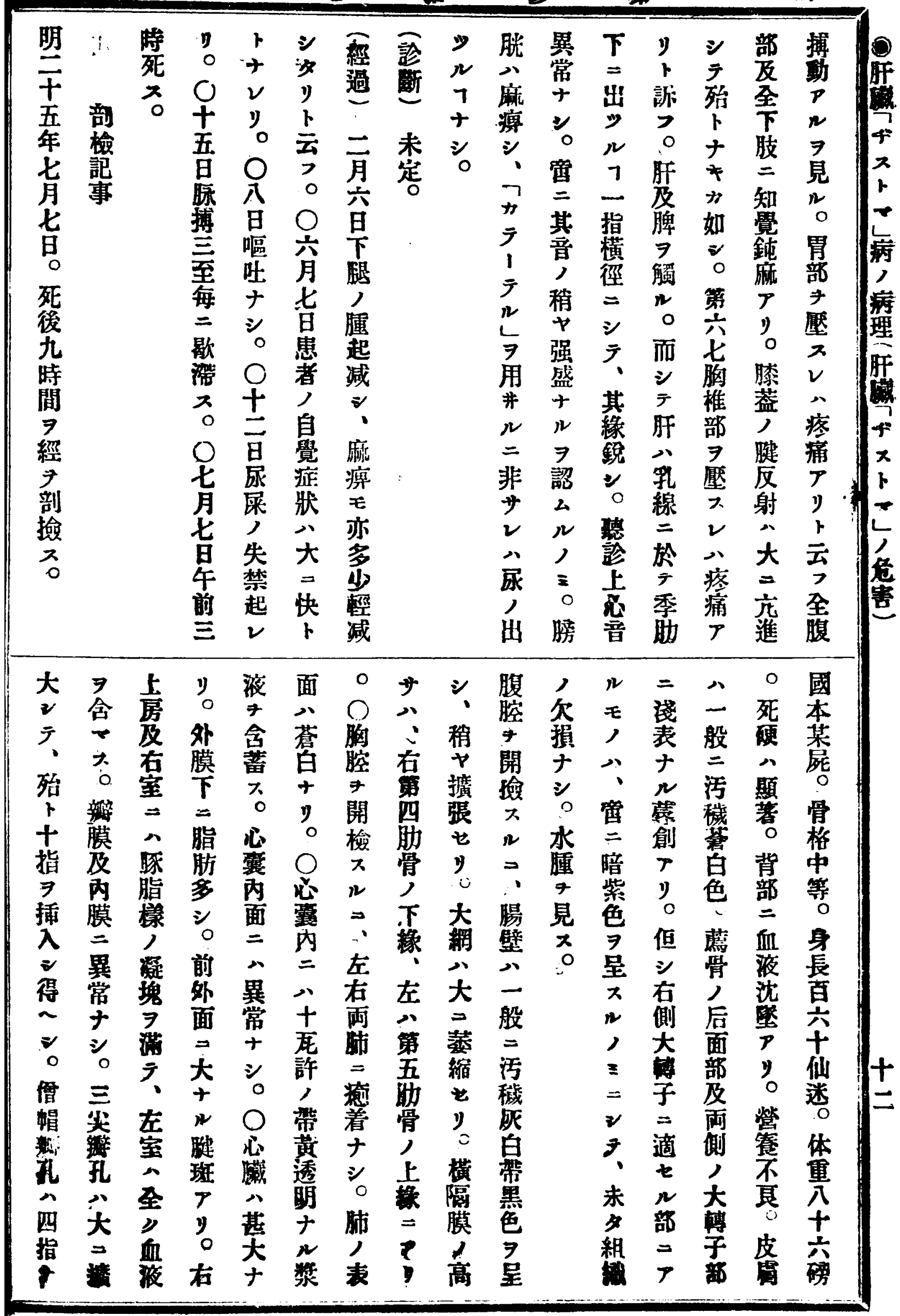




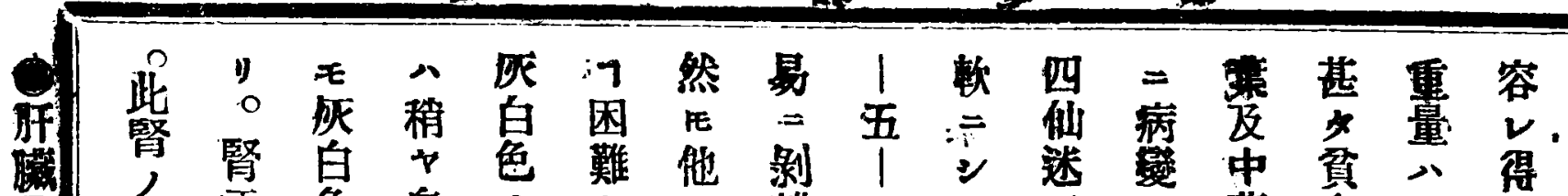

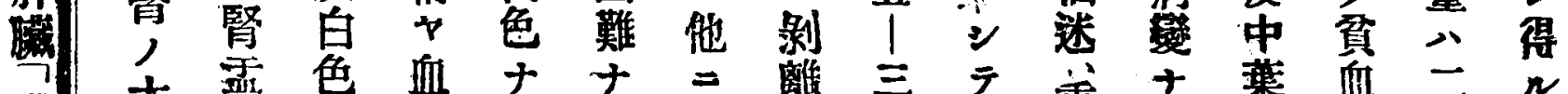

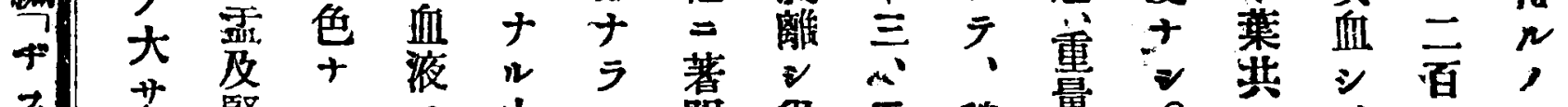

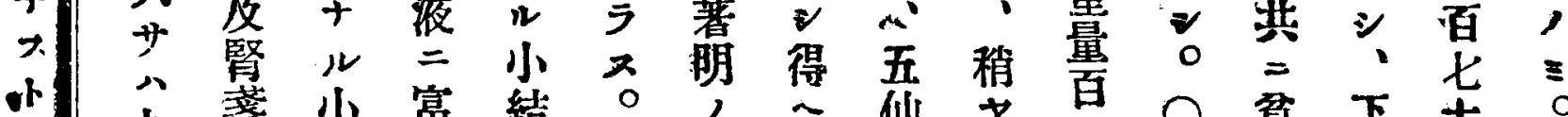

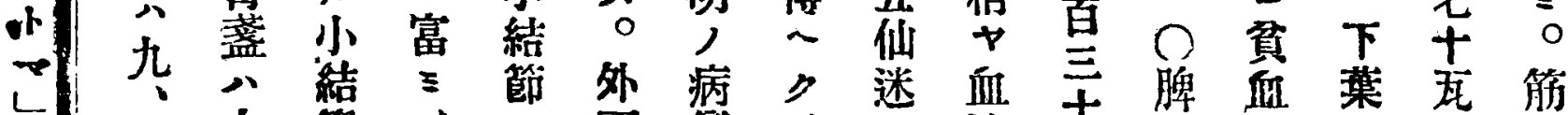

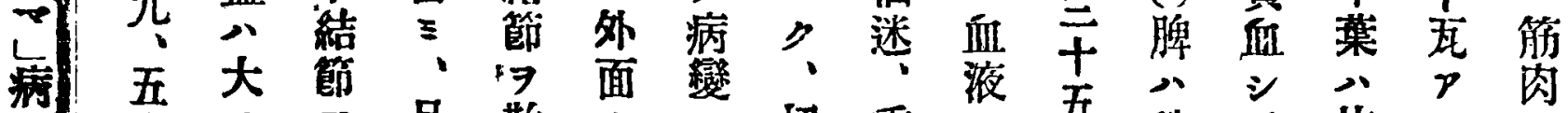

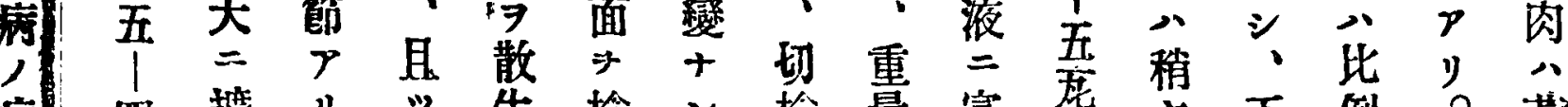

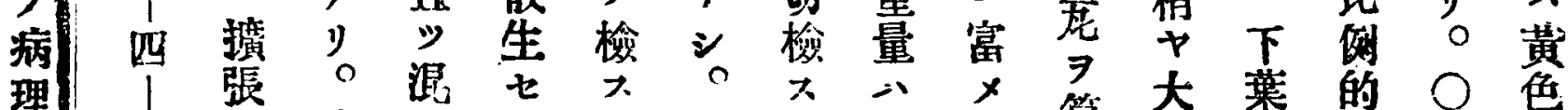

理 1 卧。罚七

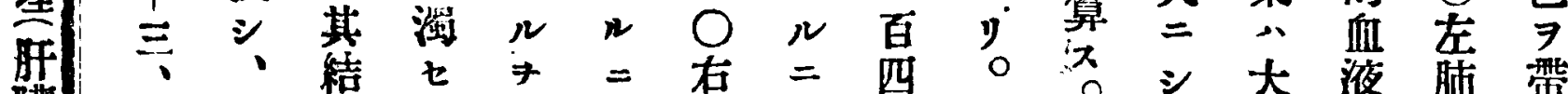

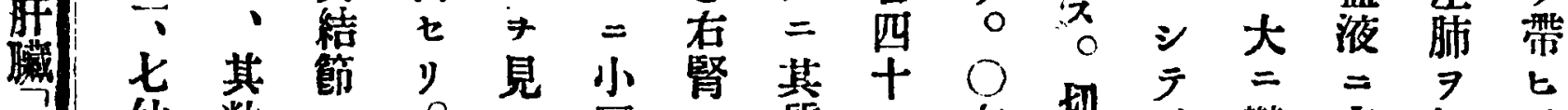

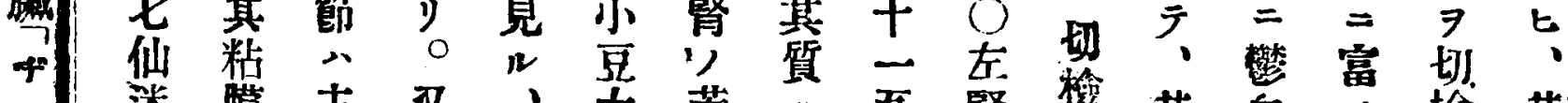

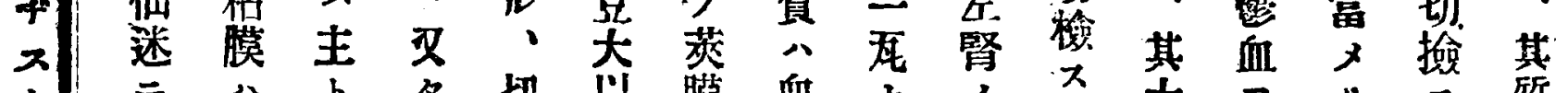

$r=$ 点

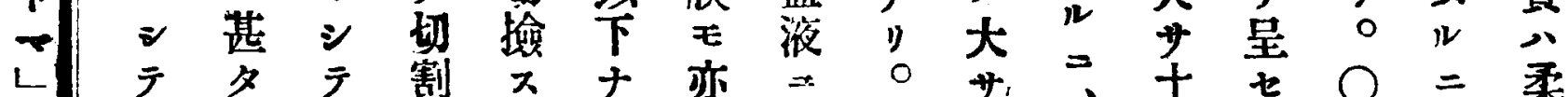

1.夕多割 スナ亦 $=0$ サ

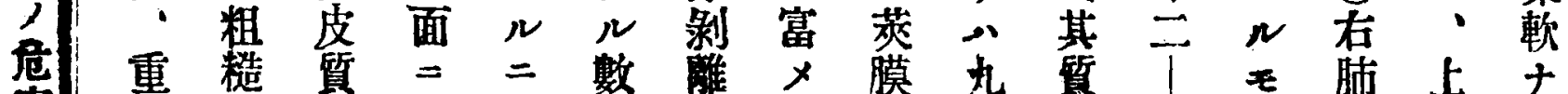

害 量 喜 於 其繁

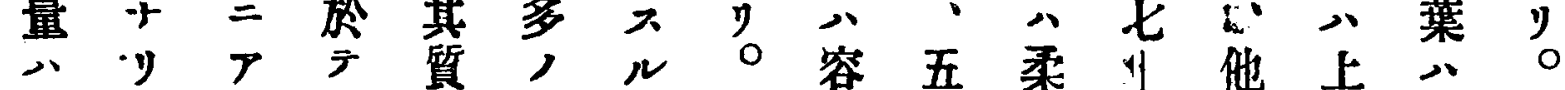

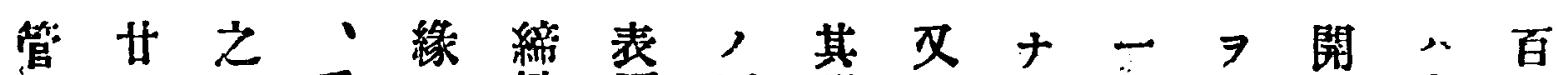

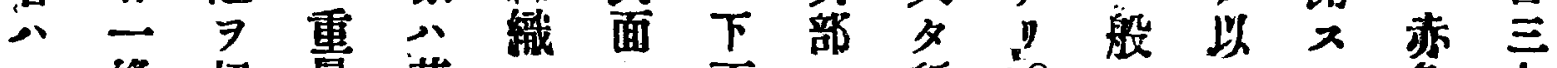
一佟切量甚,$=$ 面八所

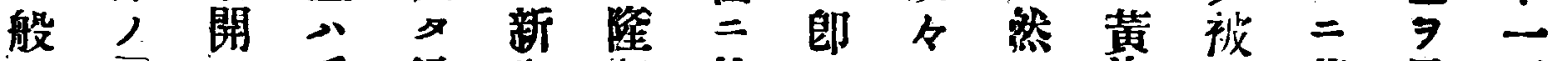

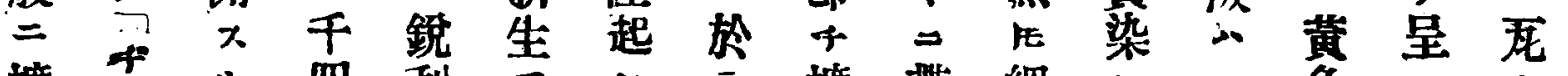

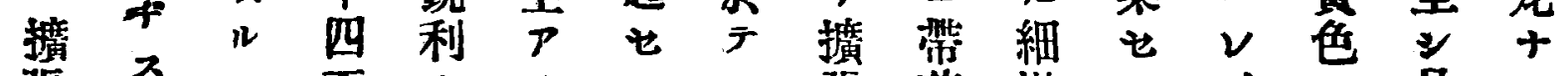

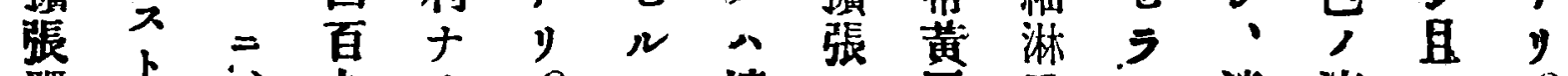
萌 $\div$ 九

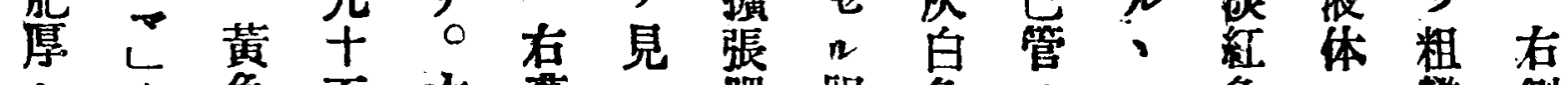
七。色五大葉

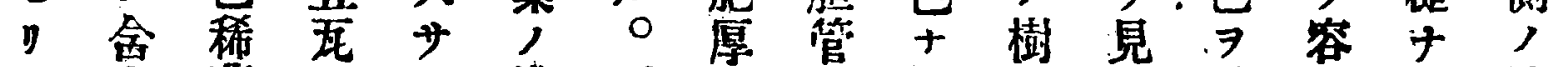

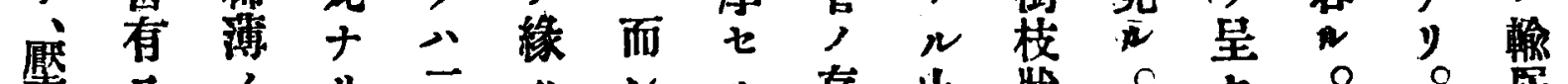

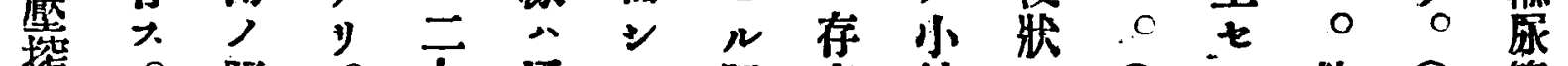

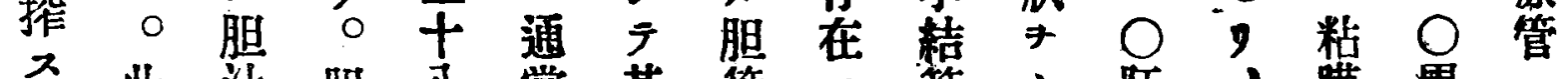

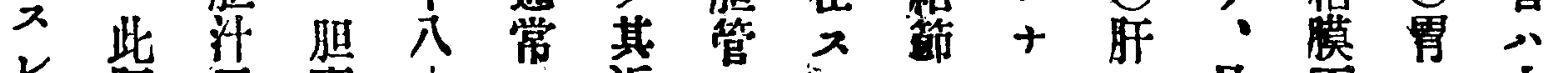

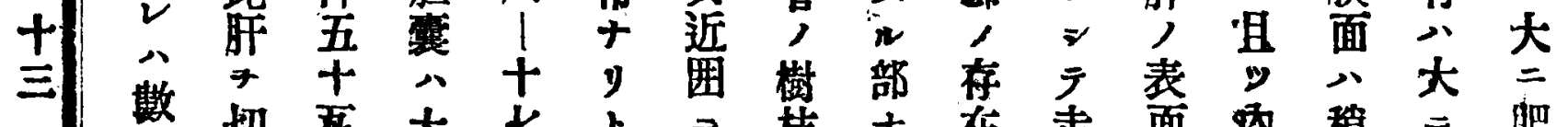

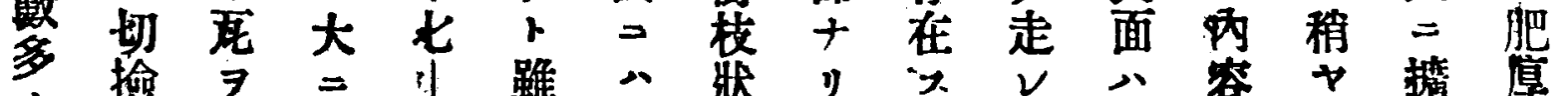

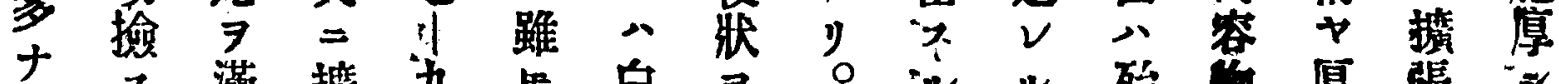

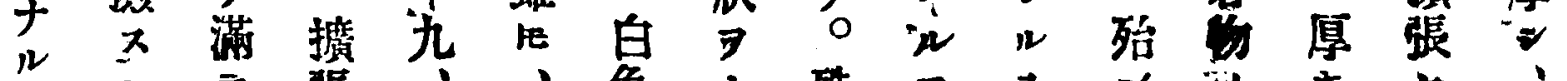
古

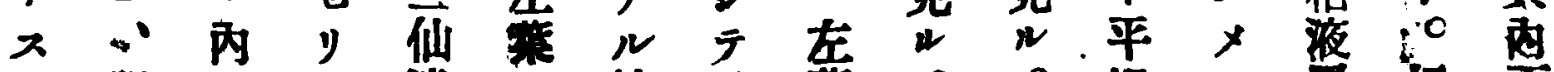

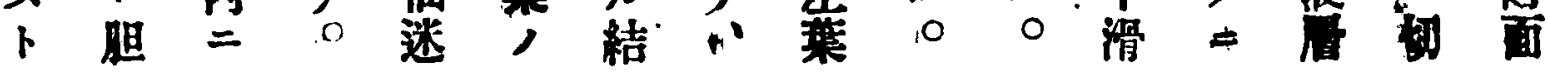




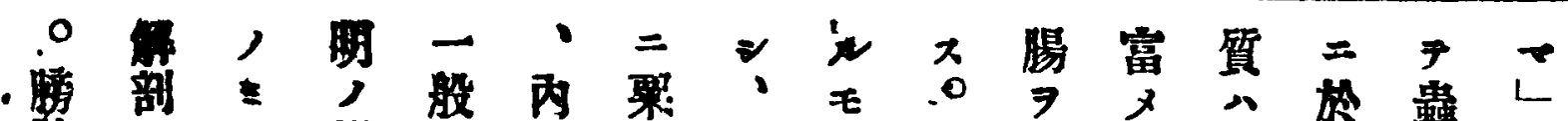

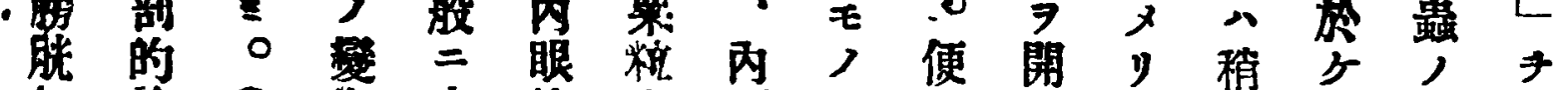
加喰 $\bigcirc$ 化充的大面 $>$ 色捡。

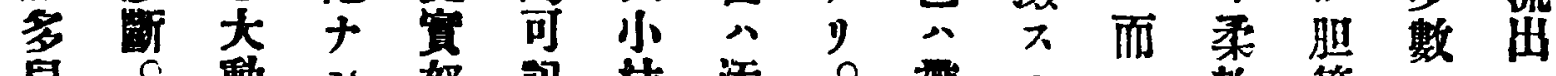

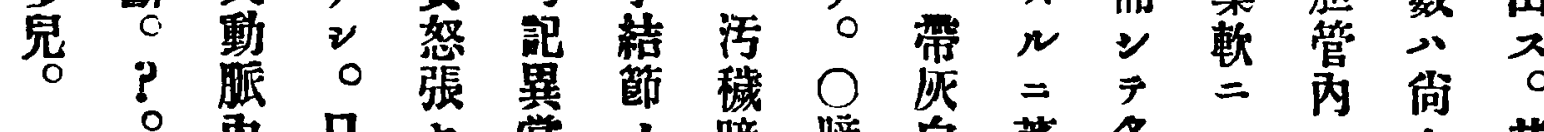
内只七常ノ暗膀白著各 訮 = 切ル十散赤㳀黄明個テ 整 ギ暗

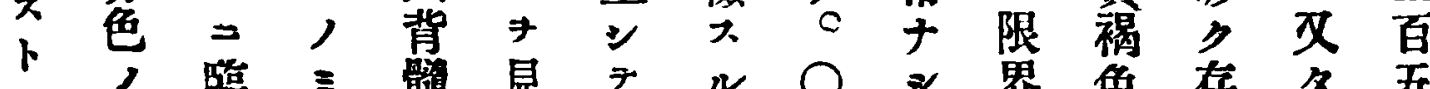

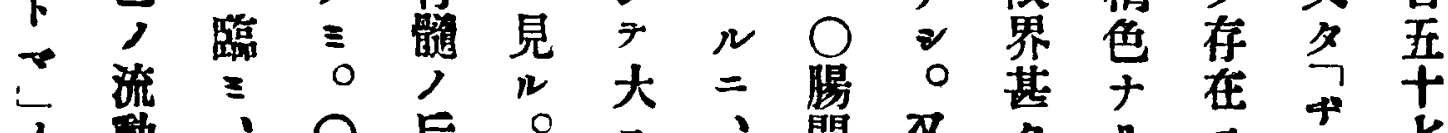

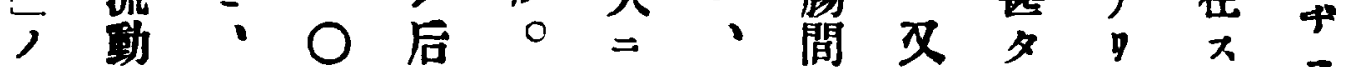
奇血血璃面 $\bigcirc$ 粗其膜夕制 0 火 ス

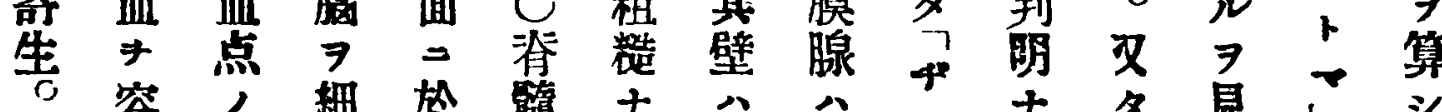

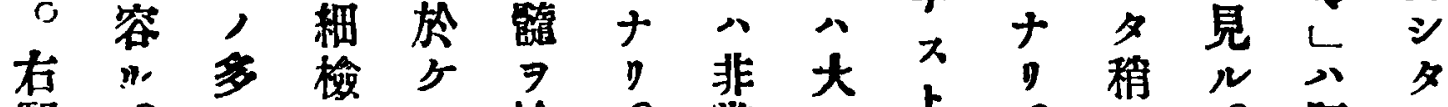
腎0 0 大 2 领 0 常 結 $\because$ 見

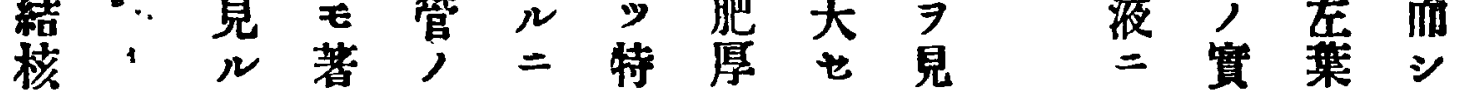

二又上出第

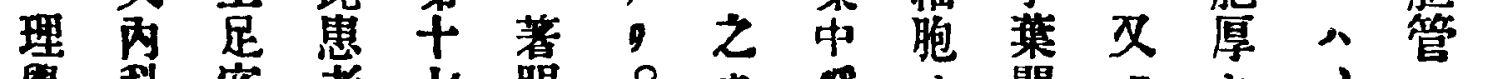

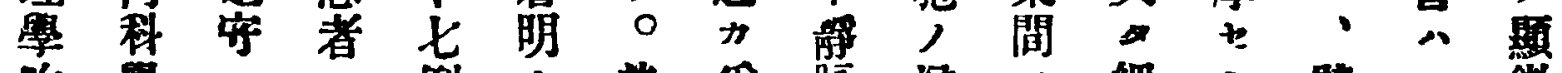

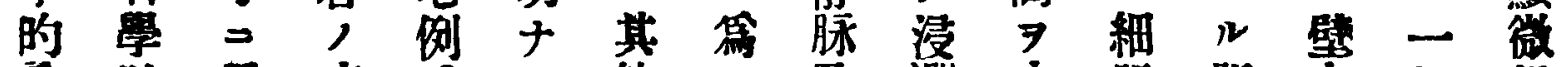
喰助居病

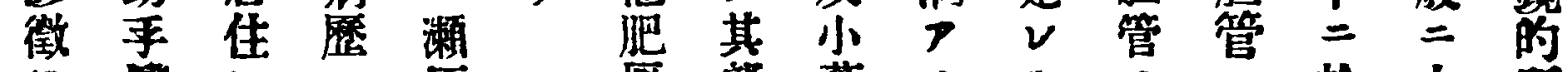

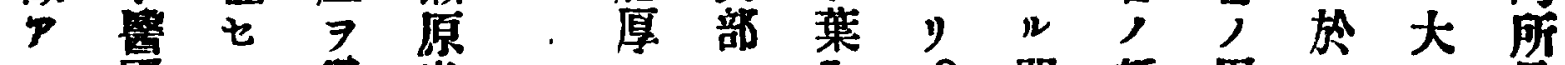

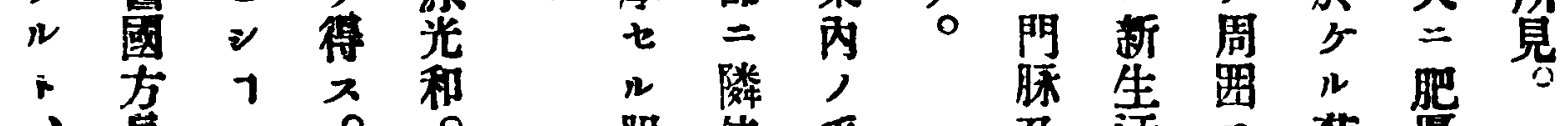
㹣長 事 然四

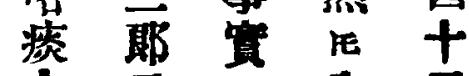

中 君 + 入 五

晡ノy完年

槠 0 前 0

$\rightarrow=$ 周

t $r^{\prime}$ 崩

$\sim v \quad$ 慗

1. $\rightarrow$ 空

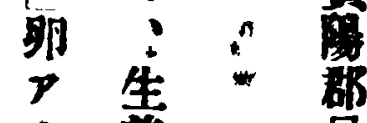

）是

年胸站标
盟位毛

管 セ 赫

三 管

隣 肝

接絊 非

せ胞常

$几 八=$

所梢 摭

> 㜊

肝蓄 せ

細 少

七胞七モ

$1>n$,

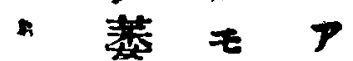

小, 》
及迁二莆厚 胆典治萄七 管 $v>$ 频 ノテ $テ$ 腺 0 種存心而 别在 大 $\Rightarrow$ 圆 $\Rightarrow$ \% 海儿茾谓 其 七 7 細息太 。見胞文 一ルノル元 般。浚 7 二 渞見

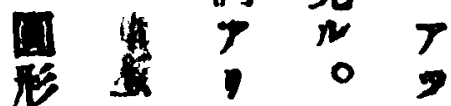




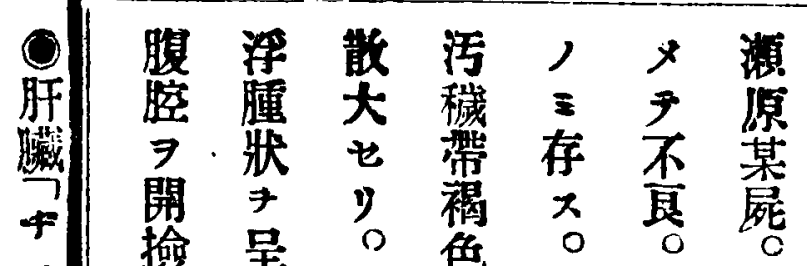

天热至胸色死死骨

上ル、腹呈斑硬禁

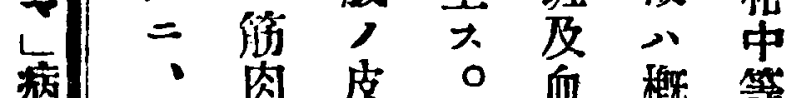

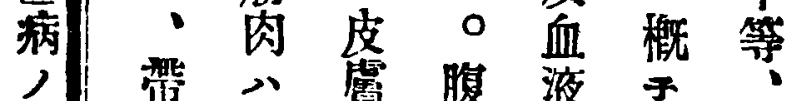

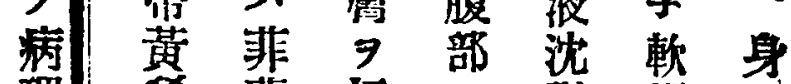

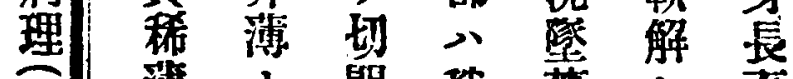

肝溥大閐稍著七百

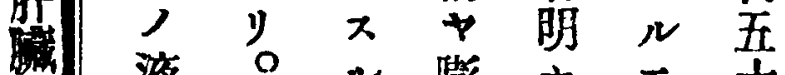

液口n膨士七早

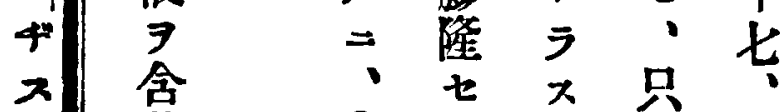

蓄皮主公无。

주 卡。皮關仙

光脂瞳膚䬣迷

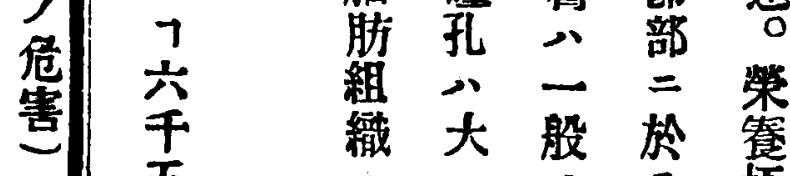

× 明

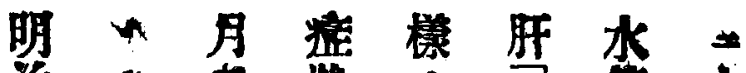

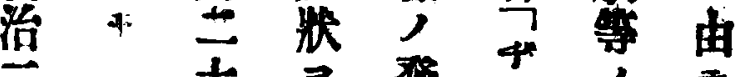

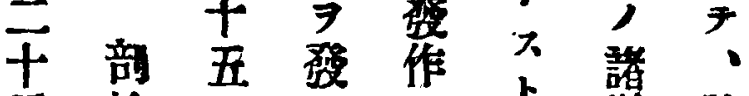

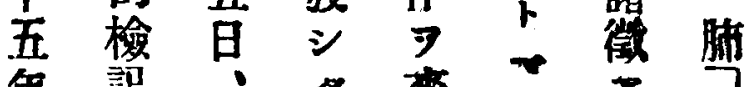

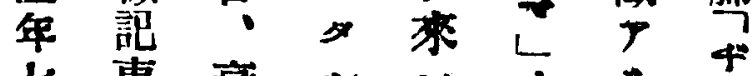
有衰

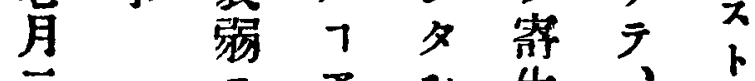

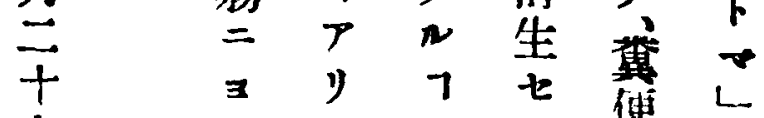

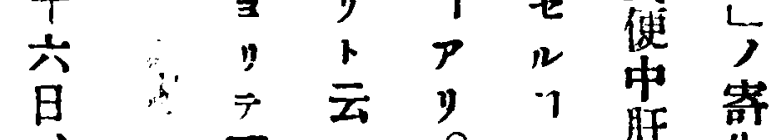

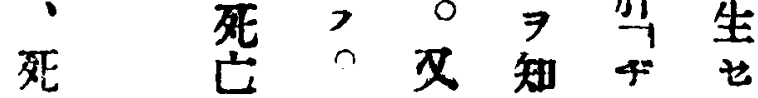

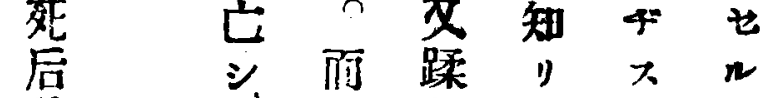
廿 $\Rightarrow=$ 狂 $\Rightarrow 1$ 四 y $テ$ 若り

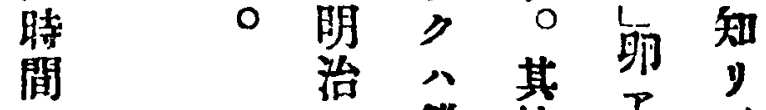
7

縃

部 掜
治 公其学 !

干䔎偪 他下

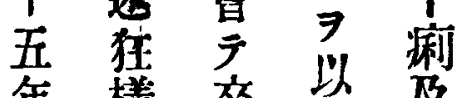

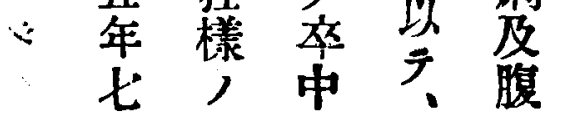

僧 $\Rightarrow$ 右夕外り心肺電部心平面實百

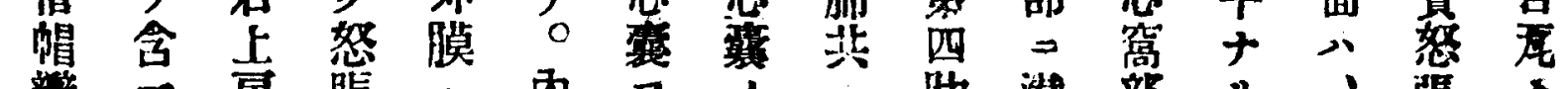
垶 房脹

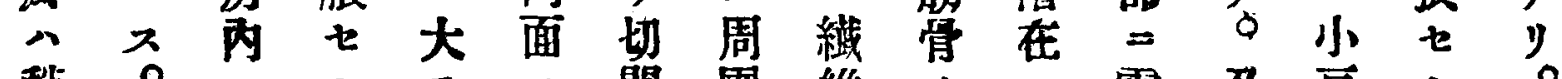
稍 $0=n=\Rightarrow$ 開園維, $x$ 露及豆山。

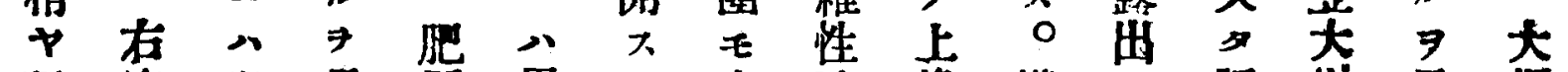
萌室半見厚 異

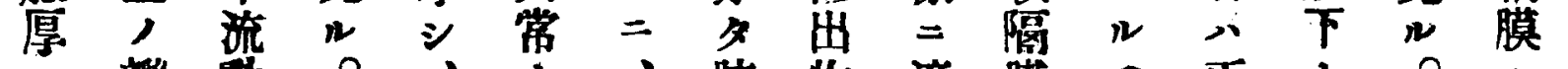

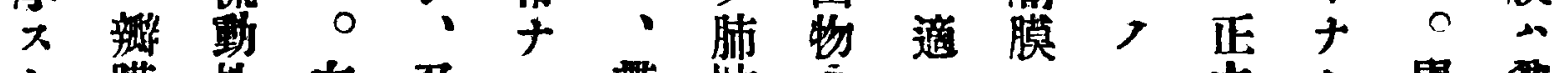

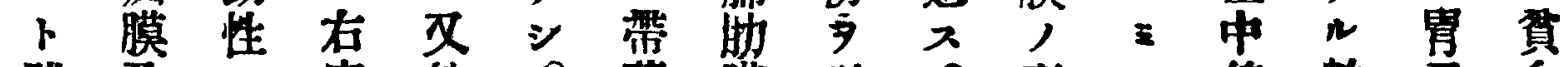

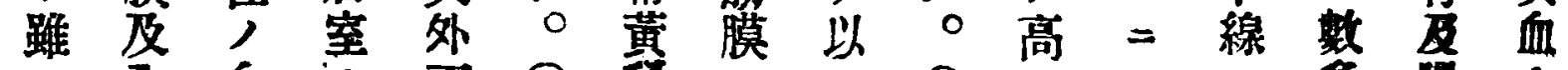

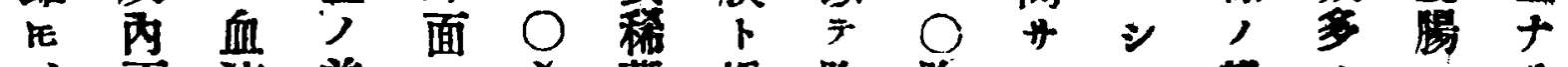

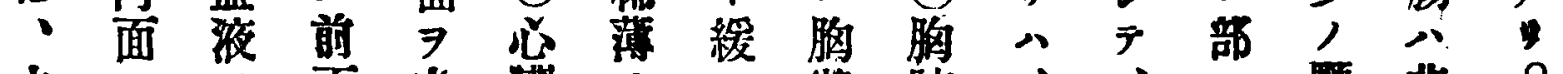

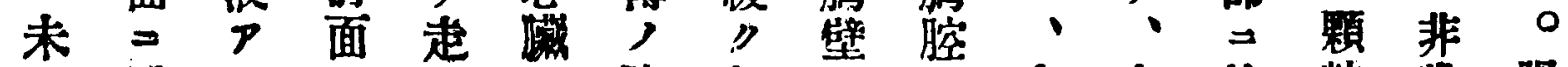

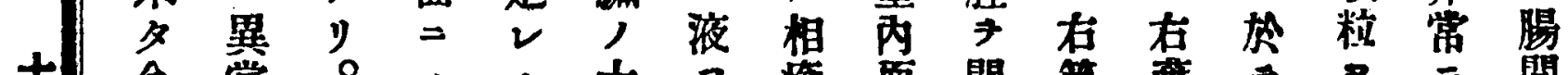

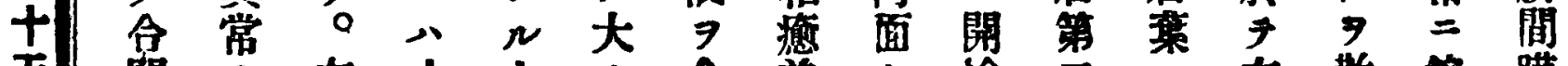

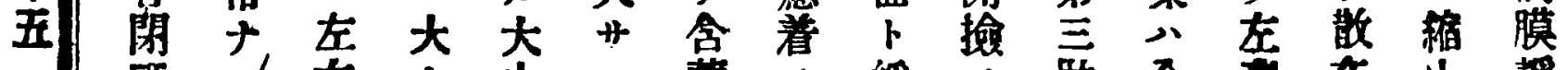

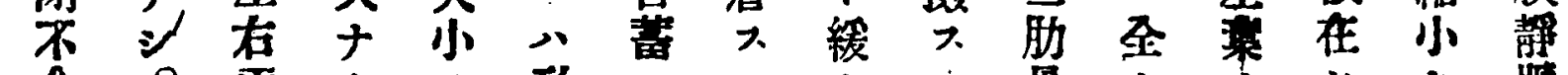

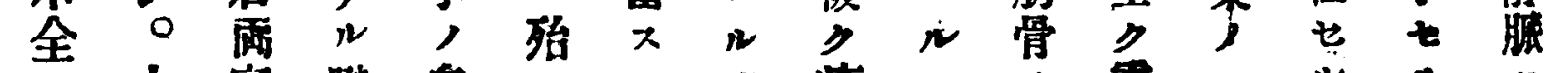

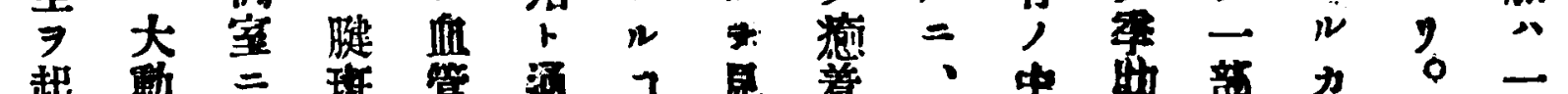

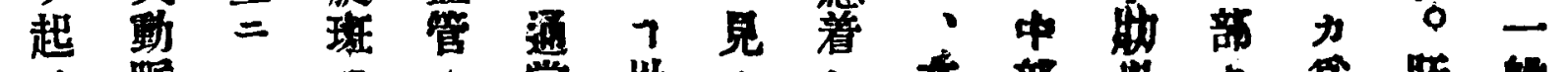
大 脤

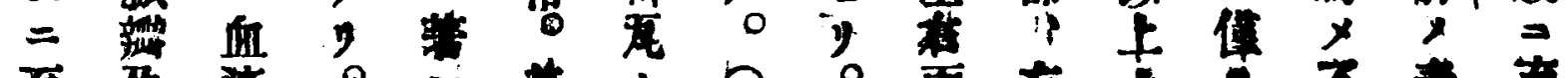
至及液。类十 


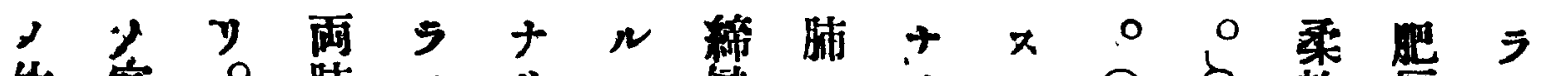

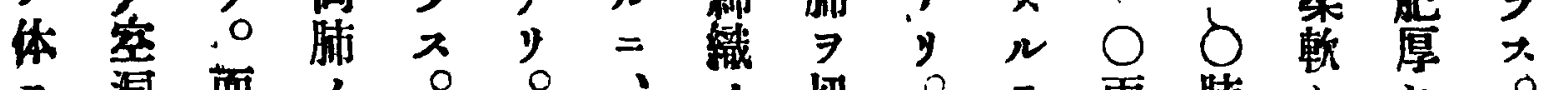

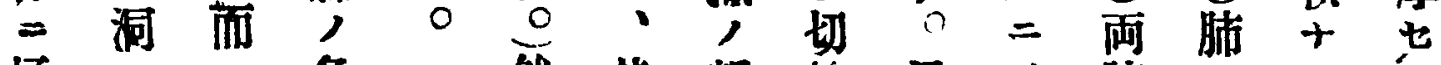

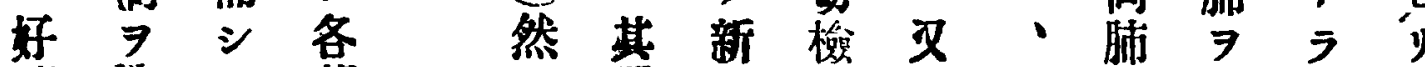
適 邀 テ都 ス 9 基 3

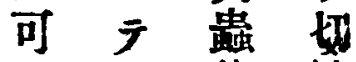
代質生 ス

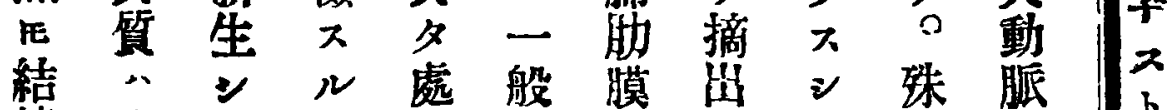
* 体 揄 空 其 洞丽舀 $>$ 本 $\frac{1}{x}$

几生秦個

毛活 動

年 0 万 肺

基两萍

网在午

$=$ 名

八胎䖵 上

キ年雀

ス ギ

$\rightarrow$ 省 見

F ᄂ 正 \&

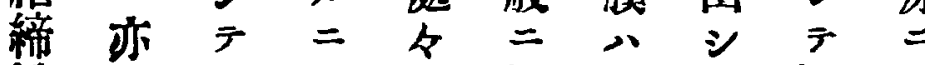

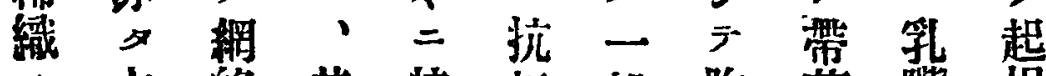
人水 絡 其 特 抵殷胸黄䠰 根

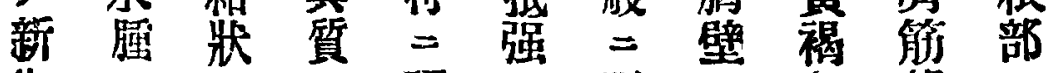

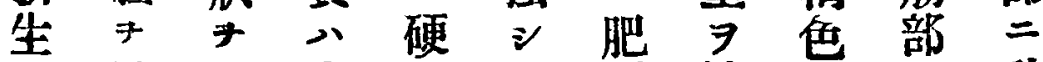
八呈十大圆。愿撿十 二 動

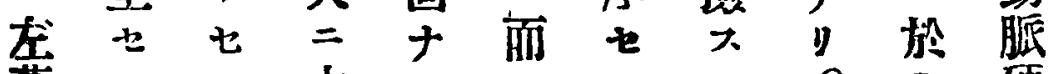

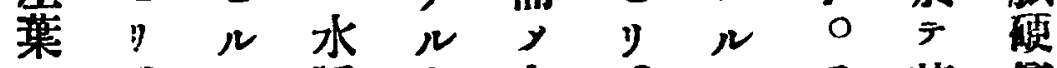
二 $\approx$ 腫小布 0 二重著 於左見 9 結脑 $\bigcirc$ 量明 $\boldsymbol{P}$ 与 肺 2 呈 節

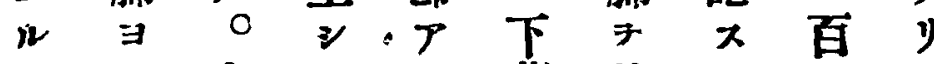

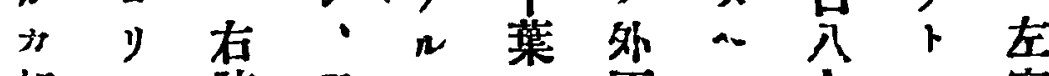
如王肺及 7 八面 $\neq+$ 大室 ク更 7 非 觸 陎 $\exists$ 異 100 甚三切常口常死觔丽 シ高检二十高按十十因面

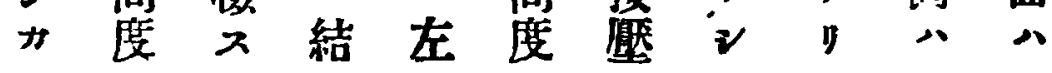

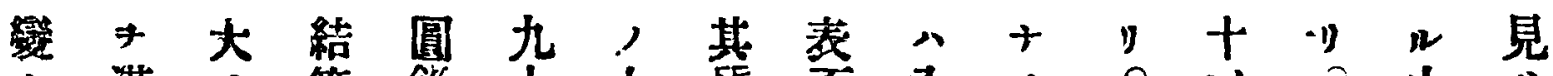

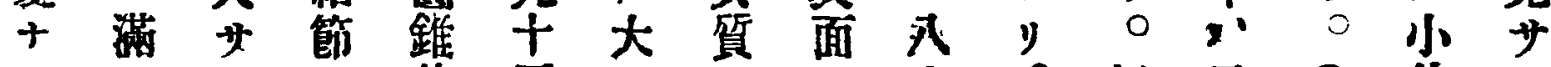
*

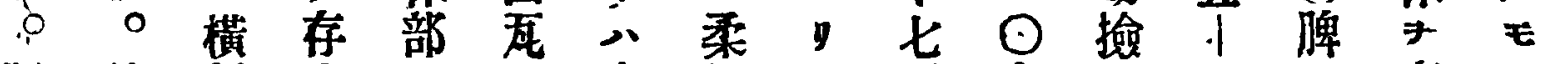

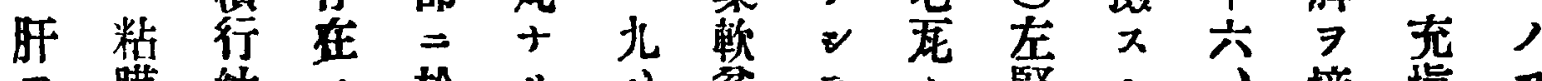

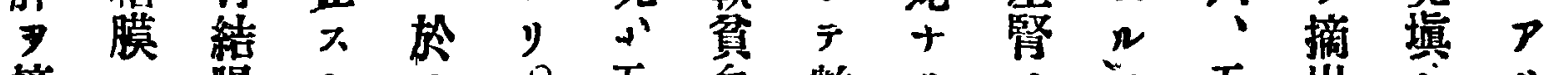

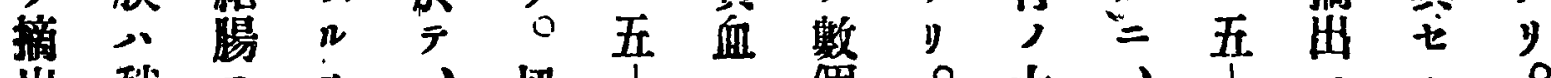
出稍 不充

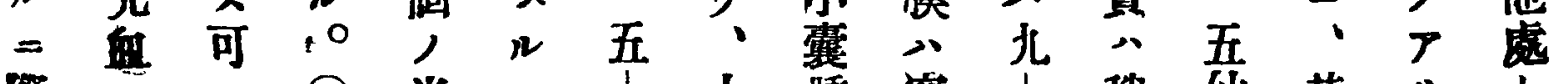

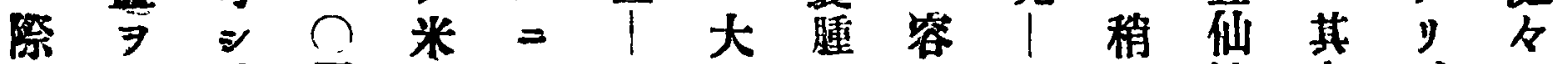
呈 0 胃 粘 $\because$ 二

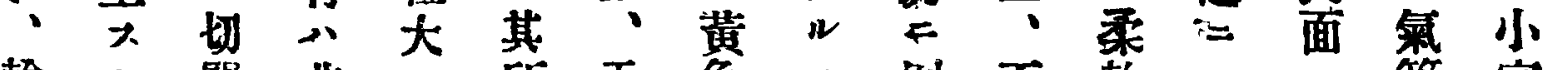

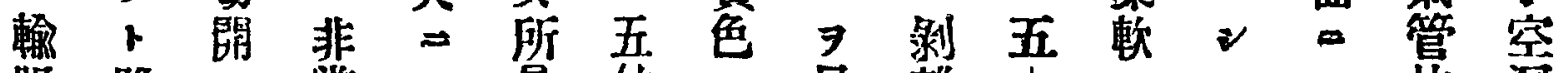

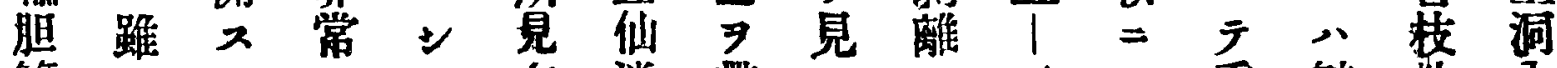

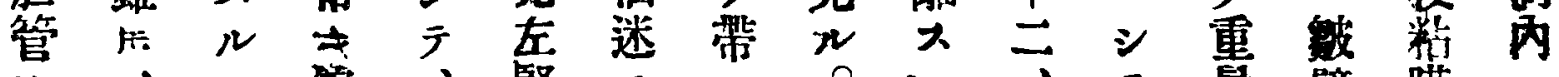

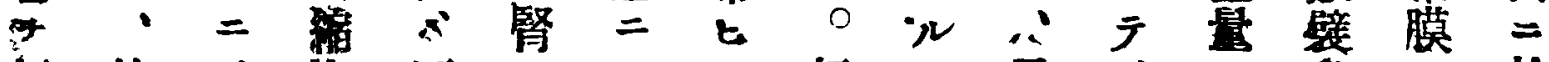

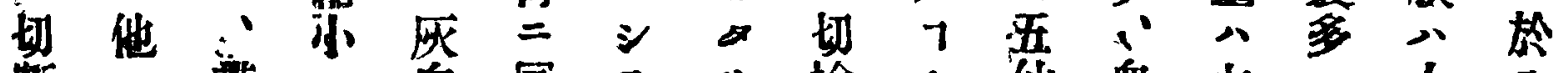

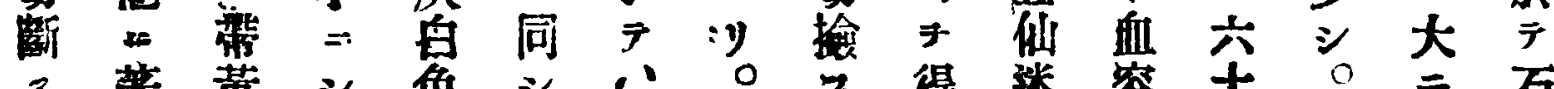
ス著黄 $シ$ 色 シ :

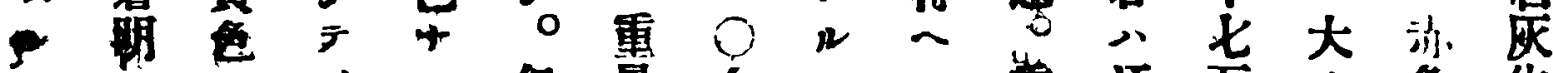
$=x y$ ”

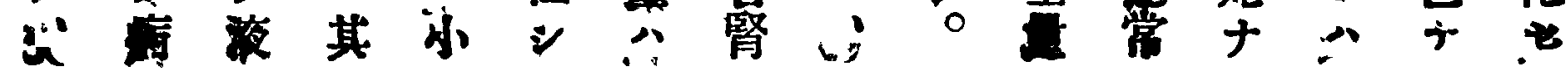


○

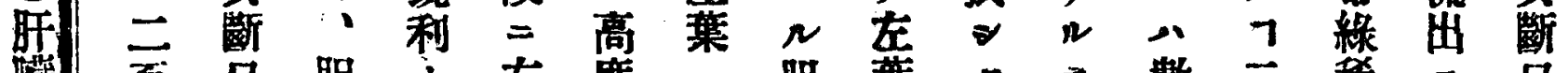

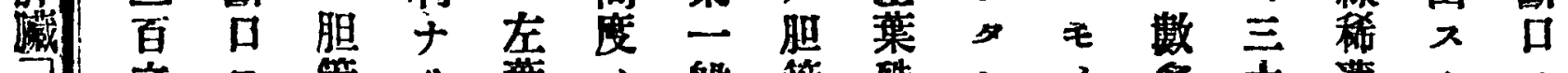

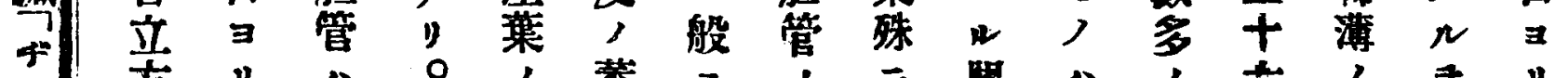

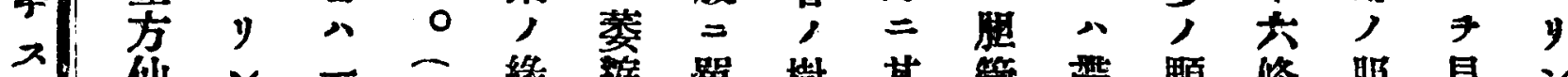
小僻

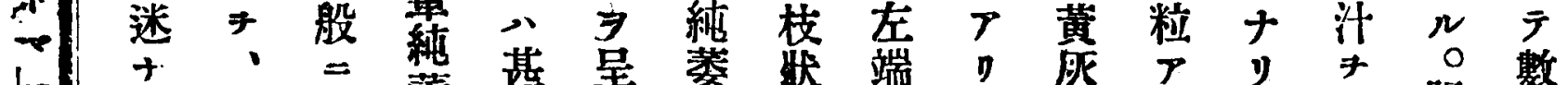

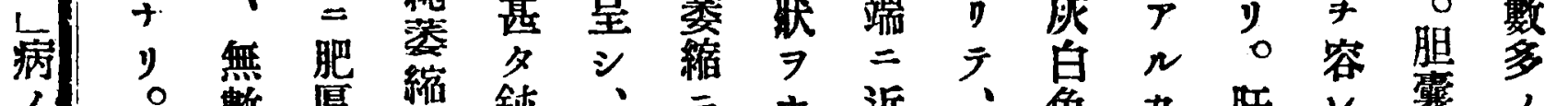

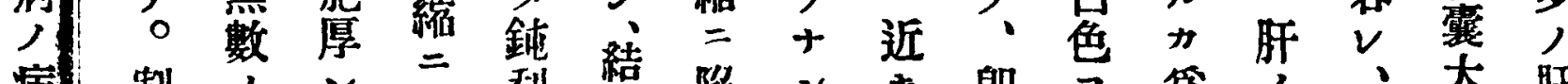

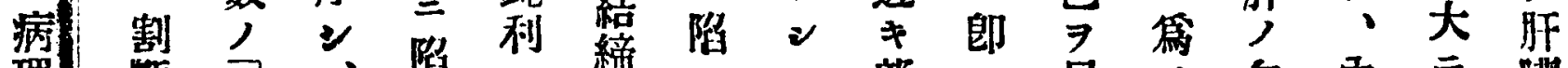
理 斷 奣 面

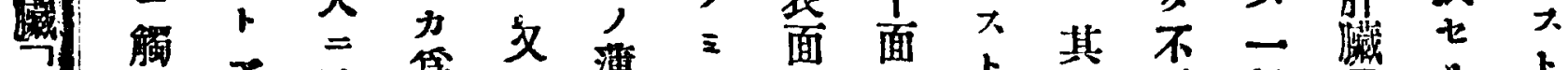

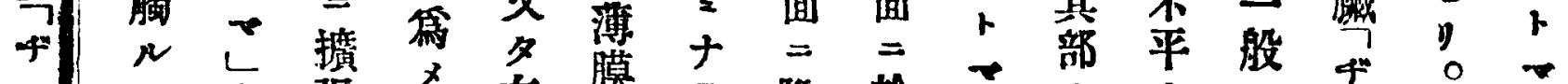
ス

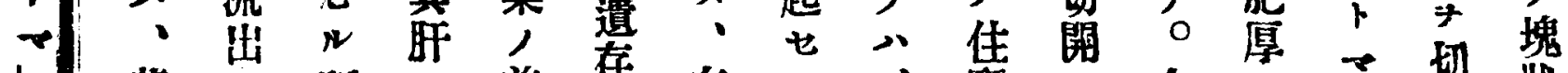

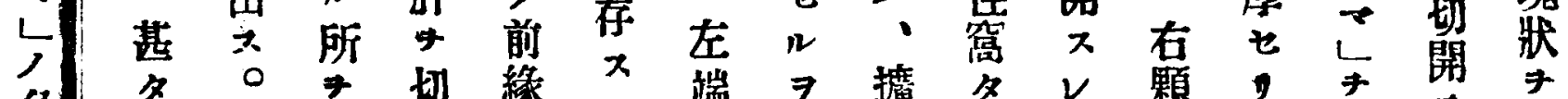
贷 粘

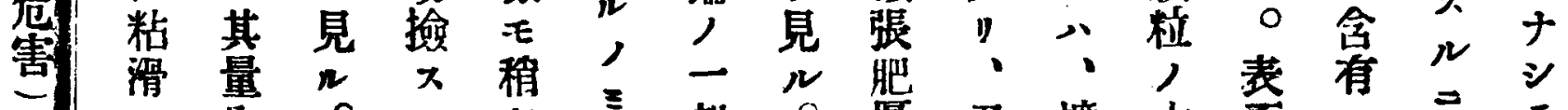

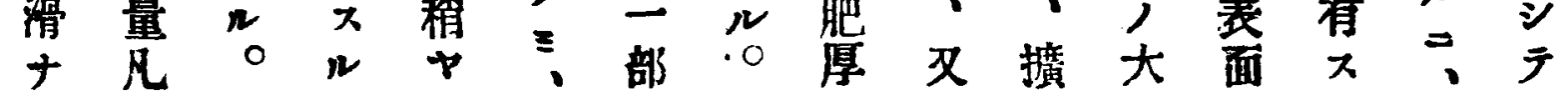

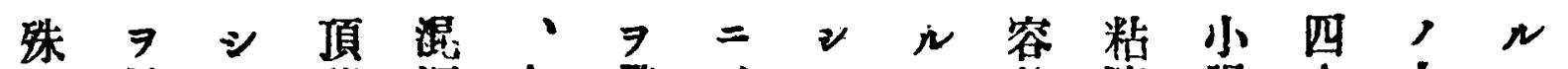

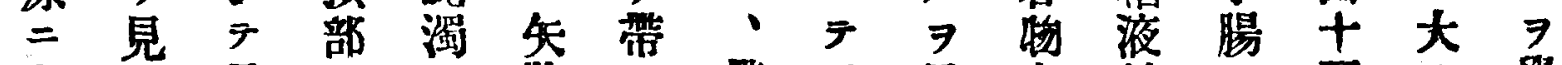

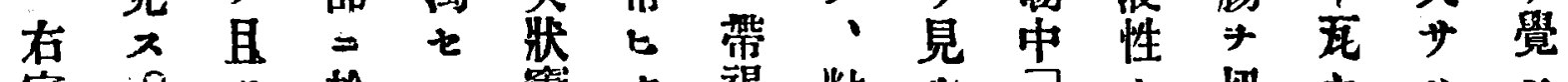

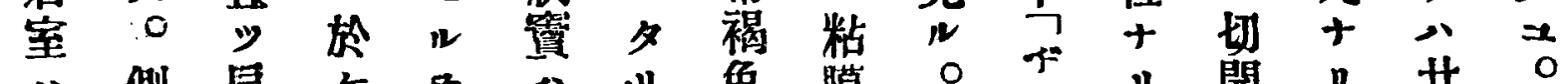

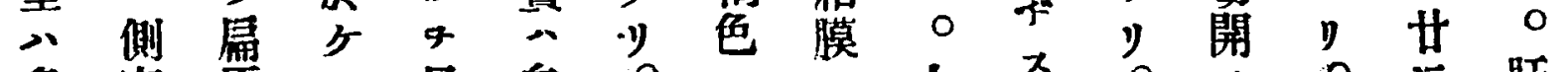

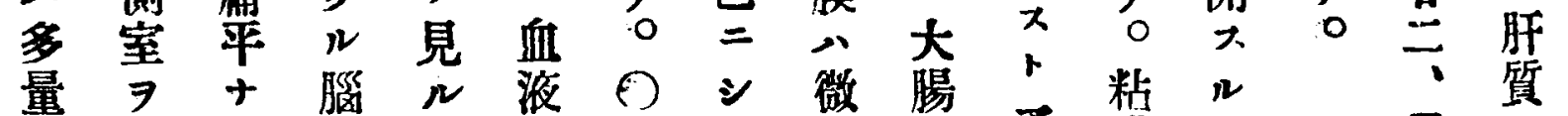

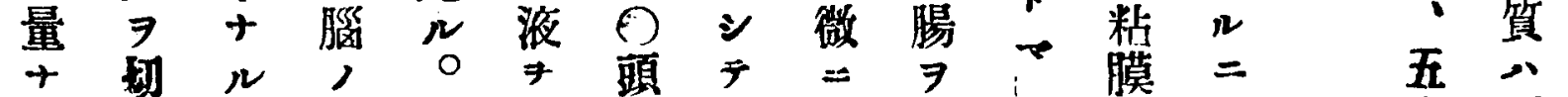

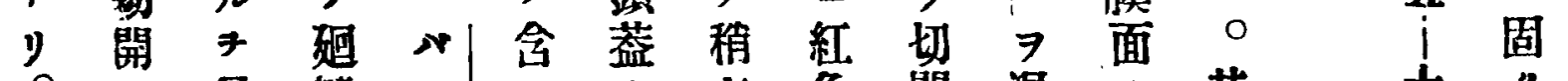
○大見䡜七七色開混 其

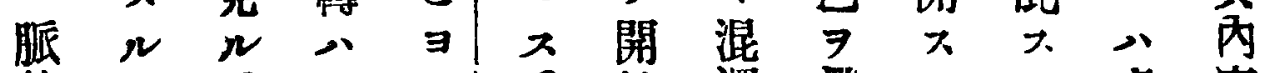

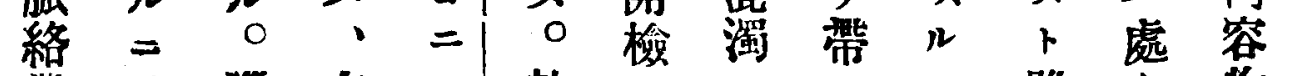
叢、腦左 1 軟 $九$ せ

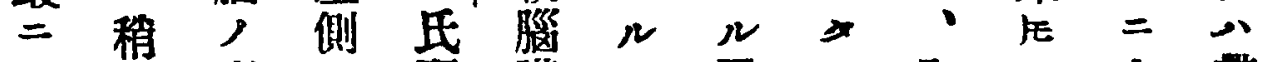
+ 硬 $\forall$ 面 此槛 七固量三下, 水硬容の物形血黑

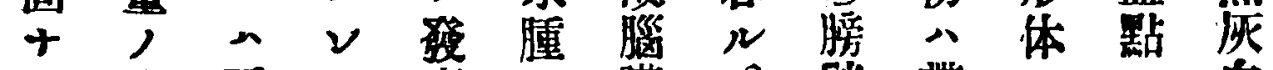

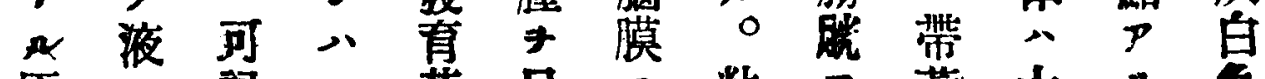

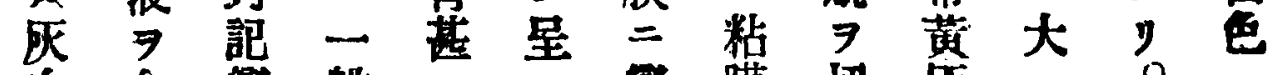

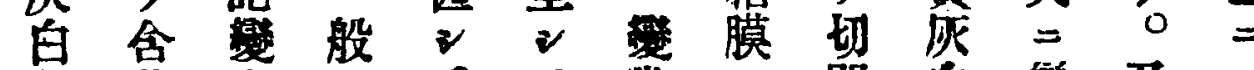

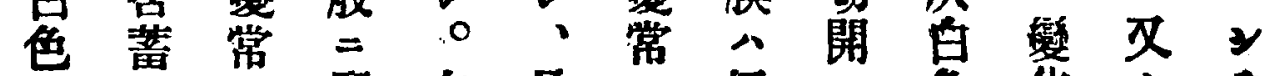

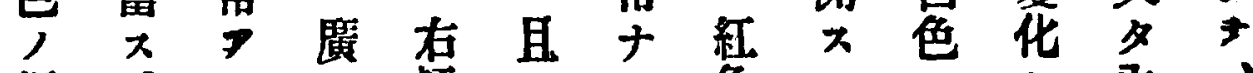

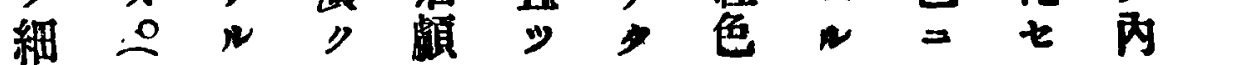




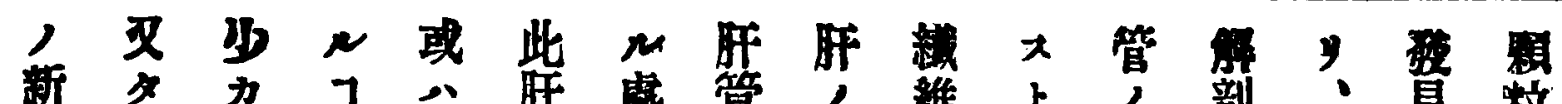
暂名

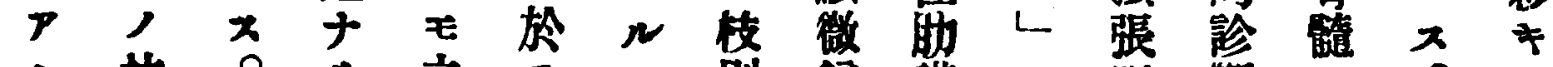

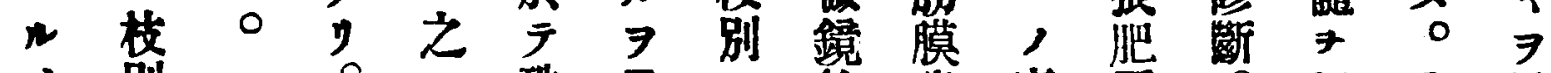

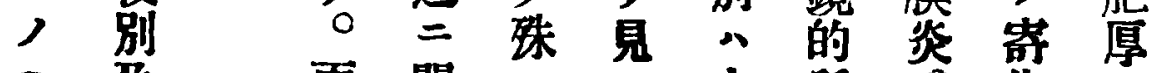

三及而關 $=N$ 大 所

+ 阴

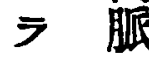
シ 係 泩。 $\rightarrow$, 于十目

- 枝 其》 2

肝 别

圂 シ

, =

形

左 沿

䎩 ‘

葉 ᄀ

胞 甚 。

$=7$

浸 学肝

$P$.

潤管

》 肥

圆

于 厚

溲 形

$\leadsto$ ナ

牀 細 別

* 胞 =

肝結

ナ, 沼

細 組

七浸 >

胞 樴

几潤 テ

處七；

穛 只 吾

芯兽 人

言公身

突突者

异 突 老

总宽 年

兄蓄至

云 家

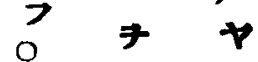

此來生

大 7 理

身 7 的

体見异

$\exists$ 富

搆世退

成人行士

七 成

吃形

細 $\exists$

胞茬要

再 萎

述
(๑)

老含毛而一毛殊

人有多蒡幋整二

菱

縮

$=$

就

$\bar{\tau}$
₹細萎，脈

* 胞 小 比壁

見了十較厂

○一。擴 例

及紀 然大的

$\Rightarrow$ 絽 $匚$ 十 肥

肝形珢几愿

細 $\exists \exists \mp+$

胞呈在, 心

人葉厂毛

多 $=0$

瓜就或於。多

八

黄不甚

褐 正

色形
或 $y$ 的此
切 $\bigcirc$ 見

(1) 背 $=$

咶捡背兄 颜

入. 部

几人 其

モ 軟 他

肉組 腦

眼

的縱 細

寄 $\Rightarrow$ 割 揄

生八 万

異 N

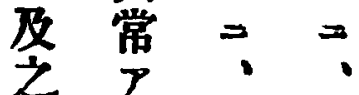

$=n$ 水異

因 7 腿 常

邓見著

盟 0 明 